\title{
CLINICAL DETERMINATION OF THE SITES OF RED CELL SEQUESTRATION IN HEMOLYTIC ANEMIAS ${ }^{1}$
}

\author{
BY JAMES H. JANDL, MORTIMER S. GREENBERG, ROBERT H. YONEMOTO, AND \\ WILLIAM B. CASTLE \\ (From the Thorndike Memorial Laboratory and Second and Fourth (Harvard), Medical Services \\ Boston City Hospital, and the Department of Medicine, Harvard Medical \\ School, Boston, Mass.)
}

(Submitted for publication January 30, 1956; accepted April 3, 1956)

The widespread application of red cell survival techniques has revealed the importance of excessive red cell destruction in the pathologic physiology of many of the anemias. An increasing array of in vitro methods for detecting red cell or serum abnormalities has provided insight into the in vivo mechanisms underlying some of these processes. In certain disease states the presence of visible or physically measurable alterations of the red cells has permitted detection of the sites and to some extent of the mechanisms of sequestration of these cells. Such valuable observations have been made upon pathologic material from patients with congenital hemolytic anemia (1-5) and sickle cell anemia $(1,5-7)$. The need has continued to exist, however, for a clinical method by which to determine the sites of red cell destruction, both for an understanding of the relationship between red cell abnormalities and the body's red cell clearing mechanisms, and for pragmatic aid in the often difficult decisions concerning splenectomy.

The potential usefulness of $\mathrm{Na}_{2} \mathrm{Cr}^{51} \mathrm{O}_{4}$-labelled red cells in the clinical determination of the sites of red cell destruction was suggested to us by observations on postmortem tissues taken from a patient with the hemolytic anemia of liver disease, who succumbed during observation of the survival of $\mathrm{Cr}^{51}$-labelled autogenous red cells. ${ }^{2}$ The $\mathrm{Cr}^{51}$ activity of the patient's splenic tissue was

1 This investigation was supported in part by a grant from the Helen Hay Whitney Foundation and by Research Grant RG3507 (C3) from the National Institutes of Health, Public Health Service.

$2 \mathrm{Cr}^{64}$ either as $\mathrm{Cr}^{51} \mathrm{O}_{4}^{--}$(8) or as $\mathrm{Cr}^{52+++}$ (9) is capable under appropriate conditions of firmly labelling red cells by chemical attachment to the hemoglobin and to the red cell membrane, respectively. For brevity, however, red cells labelled with $\mathrm{Na}_{2} \mathrm{Cr}^{\omega_{1}} \mathrm{O}_{4}$ will be described here as "Cr" ${ }^{51}$-labelled red cells." greater than that of other tissues even when correction was made for the $\mathrm{Cr}^{51}$ activity of the residual red cells. Moreover, the radioactivity of the packed red cells removed from the spleen exceeded that of a comparable sample of packed red cells from the peripheral blood. In order to investigate the possibility that $\mathrm{Cr}^{51}$-labelled red cell deposition could be determined by measuring body surface radioactivity, several questions required exploration: 1) Are the emanations of $\mathrm{Cr}^{51}$ suitable for external body scanning at safe dosage levels? 2) Does the site of tissue deposition of $\mathrm{Cr}^{51}$ following the intravenous injection of $\mathrm{Cr}^{51}$ labelled red cells necessarily indicate the site of deposition of whole red cells? 3 ) Is the turnover of $\mathrm{Cr}^{51}$ deposited in tissues sufficiently slow to provide a detectable accumulation? 4) Finally, do the results obtained confirm the information already established in certain specific instances, for example, in congenital hemolytic anemia and in sickle cell anemia? In order to investigate these questions, observations were first made on the distribution of $\mathrm{Cr}^{51}$ in normal subjects. The fate of $\mathrm{Cr}^{51}$-labelled autogenous red cells was then observed in patients with known intracorpuscular defects and, lastly, in patients with certain diseases generally characterized by excessive red cell destruction and a preliminary report (10) was made.

\section{METHODS}

$C r^{\text {s1 }}$ labelling technique. All red cell labelling was performed under sterile conditions with $\mathrm{Na}_{2} \mathrm{Cr}^{\mathrm{m}} \mathrm{O}_{4}{ }^{3}$ diluted with normal saline to a concentration of about 30 micrograms of chromium per cubic centimeter. Between 100 and 150 microcuries of $\mathrm{Cr}^{\text {st }}$ in this form were added with immediate mixing to $50 \mathrm{cc}$. of whole blood in a siliconized flask containing $12 \mathrm{cc}$. of acid-citrate-dextrose solution. The flask was then gently agitated continuously for 45

\footnotetext{
3 "Rachromate," Abbott Laboratories, North Chicago,
} Illinois. 


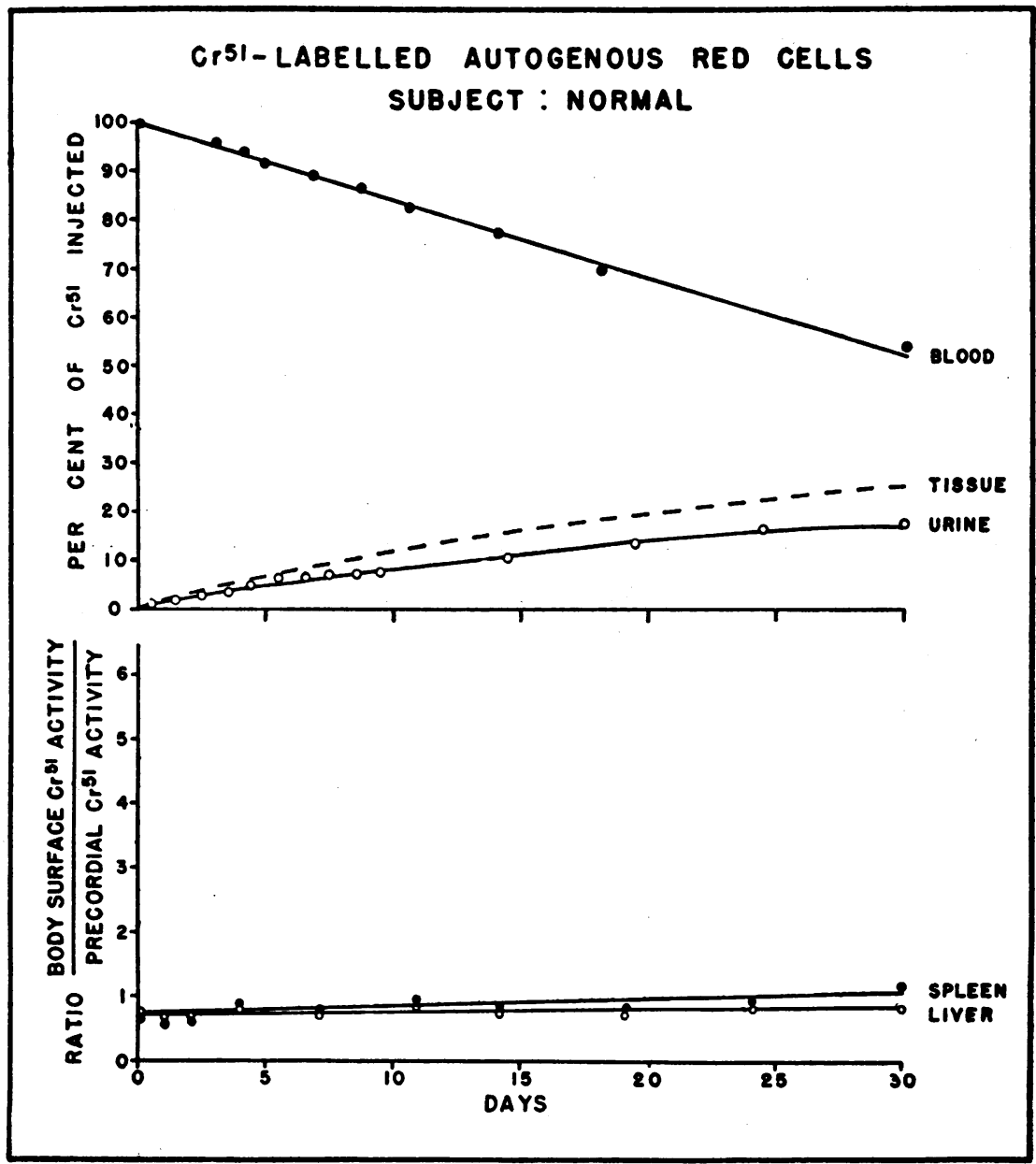

Figure 1

The gradual, almost linear, disappearance of $\mathrm{Cr}^{\mathrm{st}}$-labelled normal autogenous red cells from the blood stream shown in the upper portion of the figure is reflected by a gradual accumulation of $\mathrm{Cr}^{\mathrm{st}}$ in the tissues. Little difference exists in the levels of relative radioactivity over liver and spleen, as depicted in the lower portion of the figure.

minutes. Unbound or reduced chromium was removed by washing the red cells once in sterile normal saline, after which the red cells were suspended in 2 volumes of normal saline preparatory to injection. Over 99 per cent of the $\mathrm{Cr}^{\mathrm{st}}$ injected was in the red cells.

Solutions of $\mathrm{Cr}^{\text {st }}$-labelled hemoglobin were prepared by similarly labelling red cells which were thereafter washed 5 times in normal saline and then hemolyzed with 4 volumes of distilled water. 4 After adjusting the sodium chloride concentration of the suspending fluid to $0.85 \mathrm{gm}$. per cent, the red cell "ghosts" were centrifuged down and the supernatant solution was Seitz-filtered prior to injection.

4 It is equally feasible to label the hemoglobin in solution after hemolysis; this may be done either with $\mathrm{Na}_{2} \mathrm{Cr}^{51} \mathrm{O}_{4}$ or $\mathrm{Cr}^{51} \mathrm{Cl}_{8}$.
A solution of a reduction product of $\mathrm{Na}_{2} \mathrm{Cr}^{51} \mathrm{O}_{4}, \mathrm{Cr}^{\mathrm{s}} \mathrm{Cl}_{8}{ }^{5}$ was diluted with normal saline to a suitable volume; this was injected directly intravenously in one instance and after preliminary incubation with serum in another.

Specimen collection and $C^{\text {mil }}$ determination. Following injection of $\mathrm{Cr}^{\mathrm{N}}$-containing preparations, venous blood specimens were collected at appropriate intervals in bottles containing dry "balanced" oxalate. Their radioactivity was determined after hemolysis by freezing and thawing. Specimens for the measurement of plasma radioactivity were drawn into saline-wetted syringes and the citrated plasma removed after centrifugation of the specimens within one hour of their procurement. The plasma samples were then frozen and thawed along with

5 Radioactive chromic chloride, Abbott Laboratories, North Chicago, Illinois. 
the whole blood samples. Plasma $\mathrm{Cr}^{\text {s2 }}$ activity was expressed as a percentage of the whole blood activity by correction for the plasma volume of a sample of whole blood. When possible, all urine was collected as individual specimens for about 18 hours after the $\mathrm{Cr}^{\text {s1 }}$ injection, and thereafter 24-hour urine collections were made. In several subjects serial 2- or 4-day total stool collections were made. The stool specimens were digested with 10 per cent sodium hydroxide and mixed in a blender before sampling.

The radioactivity of all types of materials was determined with a well-type scintillation counter. The "zerotime" peripheral blood radioactivity was estimated by extrapolation of a line drawn visually through points on semilogarithmic graph paper on which the concentration of whole blood $\mathrm{Cr}^{\text {s2 }}$ was plotted against time. From this value the initial blood volume was calculated by the dilution principle and the $\mathrm{Cr}^{\mathrm{BS}}$ concentration of the circulating blood was thereafter expressed as a percentage of the zero time value. The $\mathrm{Cr}^{\mathrm{si}}$ content of the circulating blood was calculated as the product of the blood $\mathrm{Cr}^{\text {sa }}$ concentration and the blood volume, by making the assumption that the latter was unchanged during the period of study. Red cell survival at any time was then taken as the percentage of the injected $\mathrm{Cr}^{\mathrm{s1}}$ which remained in the circulating blood. For graphic presentation data so obtained were plotted against time on rectilinear graph paper without correction for $\mathrm{Cr}^{\text {sh }}$ "elution" from the red cells. The blood $\mathrm{Cr}^{51}$ activity was followed in most subjects until its disappearance. However, for easier com-

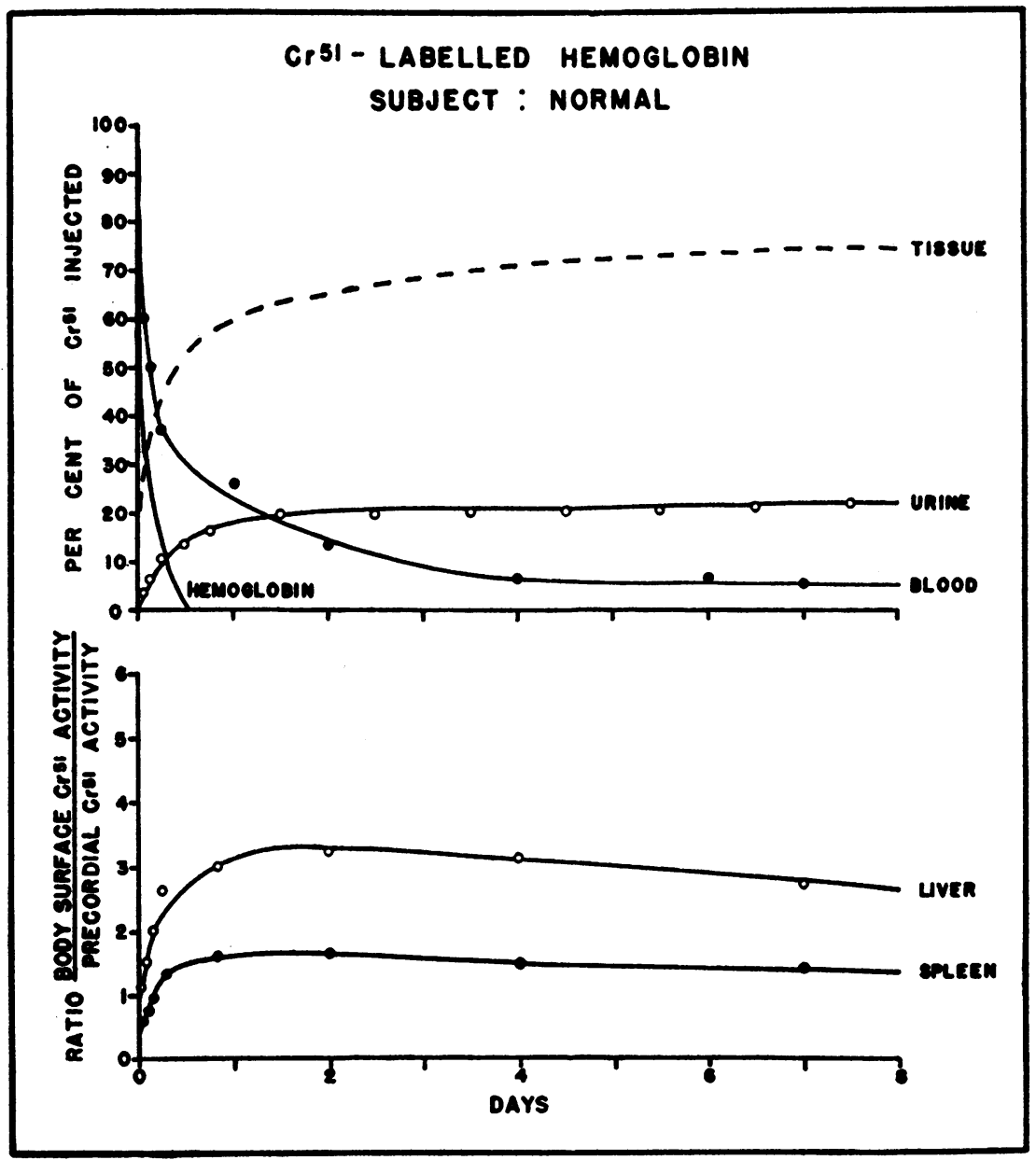

Figure 2

Following intravenous injection of $\mathrm{Cr}^{\text {st }}$-labelled hemoglobin solution, radioactivity disappeared from the blood at a continuously slowing rate with a half-disappearance time of 3 hours, whereas by chemical determination plasma hemoglobin was removed from the circulation "exponentially" with a half-time of from $11 / 2$ to 2 hours. With the removal of $\mathrm{Cr}^{\text {sh }}$ from the peripheral blood, there was a rapid, prominent rise in radioactivity over the liver and to a lesser extent over the spleen. 


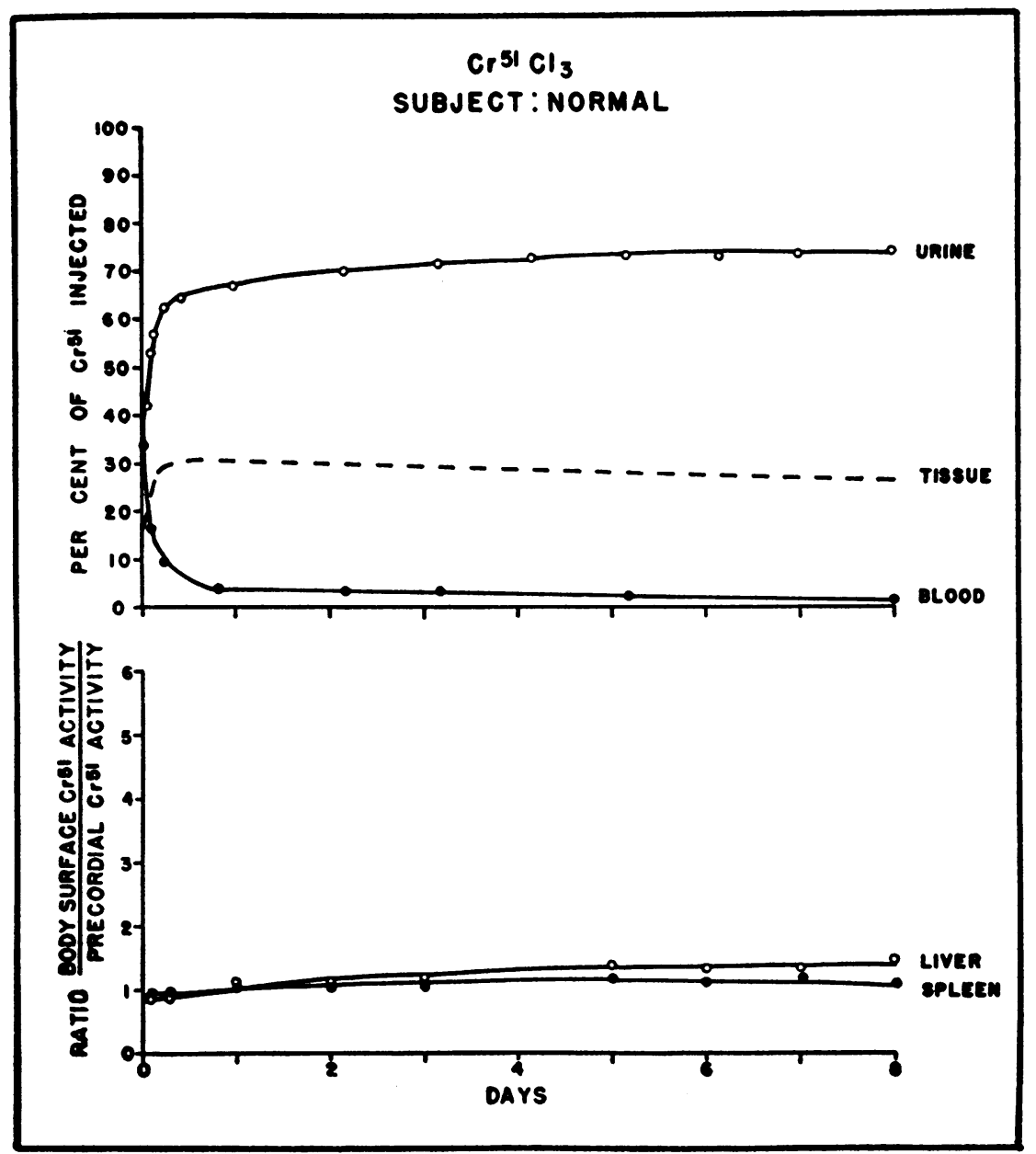

Figure 3

The upper portion of this figure indicates the great rapidity with which injected cationic trivalent $\mathrm{Cr}^{32}$ in saline is cleared from the circulation. Most of this chromium appeared in the urine, with only a slight accumulation by the liver and spleen. Preliminary incubation of $\mathrm{Cr}^{31} \mathrm{Cl}_{8}$ and serum before injection enhanced the relative $\mathrm{Cr}^{\text {s1 }}$ uptake by the liver.

parison of data, a time axis of only 30 days was employed in the presentation of the studies of individual patients shown below in Figures 1 to 13 . The urinary excretion of $\mathrm{Cr}^{\mathrm{s1}}$ was expressed as the cumulative percentage of the injected dose of $\mathrm{Cr}^{\mathrm{bl}}$. Since in no instance was $\mathrm{Cr}^{51}$ excreted in the patients' stools, the chromium not accounted for in blood or urine was designated as "tissue $\mathrm{Cr}^{\mathrm{s1}}$ " in the figures and in Table I.

Body surface counting. Body surface counting was performed with a directional scintillation counter having a conical collimator 4 inches in depth and 3 inches in internal diameter at the open end. Twenty minutes after the injection of materials labelled with $\mathrm{Cr}^{\text {an }}$, each patient was scanned. In no instance among the patients reported here were high levels of activity found other than over the heart, liver, or spleen. In each patient, there- fore, surface projections of these organs were determined by physical examination and their approximate centers were marked with a skin pencil. In some patients radioactivity levels were also followed over the thoracic, lumbar and sacral areas. In performing each count the scintillation counter was plumb-centered over the appropriate mark with the patient in a standardized position, permitting the body surface overlying the organ to approximate parallelism with the collimator surface. The counter was then lowered to direct apposition with the body surface and two or more measurements were made with an automatic scaler.

In measuring the body surface radioactivity, it was recognized that a variable but important degree of radioactivity over each organ derived from the activity of the perfusing blood, as well as from stray radiation from one 
organ to another. Since the geometric complexities involved prevented calculation of the absolute levels of organ radioactivity, a relative expression was employed. The precordial $\mathrm{Cr}^{61}$ activity grossly paralleled the activity of whole blood specimens and presumably emerged largely from the perfusing blood. ${ }^{6}$ Body surface counts were therefore expressed as the ratio of the radioactivity over a certain organ to that at the same time over the heart. This ratio represents a function of the quantity of $\mathrm{Cr}^{\mathrm{s}_{1}}$ accumulated in the organ concerned, whether in red cells

${ }^{6}$ It is apparent, however, that precordial radioactivity reflects blood radioactivity most accurately when there is the least stray irradiation from neighboring organs such as the spleen. or not, and may be regarded as a crude measure of a gradient between the organ and the circulating blood.

Miscellaneous techniques. Plasma and urine hemoglobin levels were measured by a photoelectric adaptation (11) of the benzidine method of Bing and Baker. The mean normal value for plasma hemoglobin concentration in this laboratory is $2.6 \pm 1.2 \mathrm{mg}$. (2 S.D.) per cent.

Clinical material. The "normal" subjects studied were elderly males hospitalized for minor illnesses and/or for sociologic reasons. Three of these were given autogenous $\mathrm{Cr}^{\mathrm{st}}$-labelled red cells. The 11 anemic patients displayed findings characteristic of their diseases. A brief summary of the vital statistics and of some of the hematologic data from these 14 subjects and patients is presented in Table $I$.

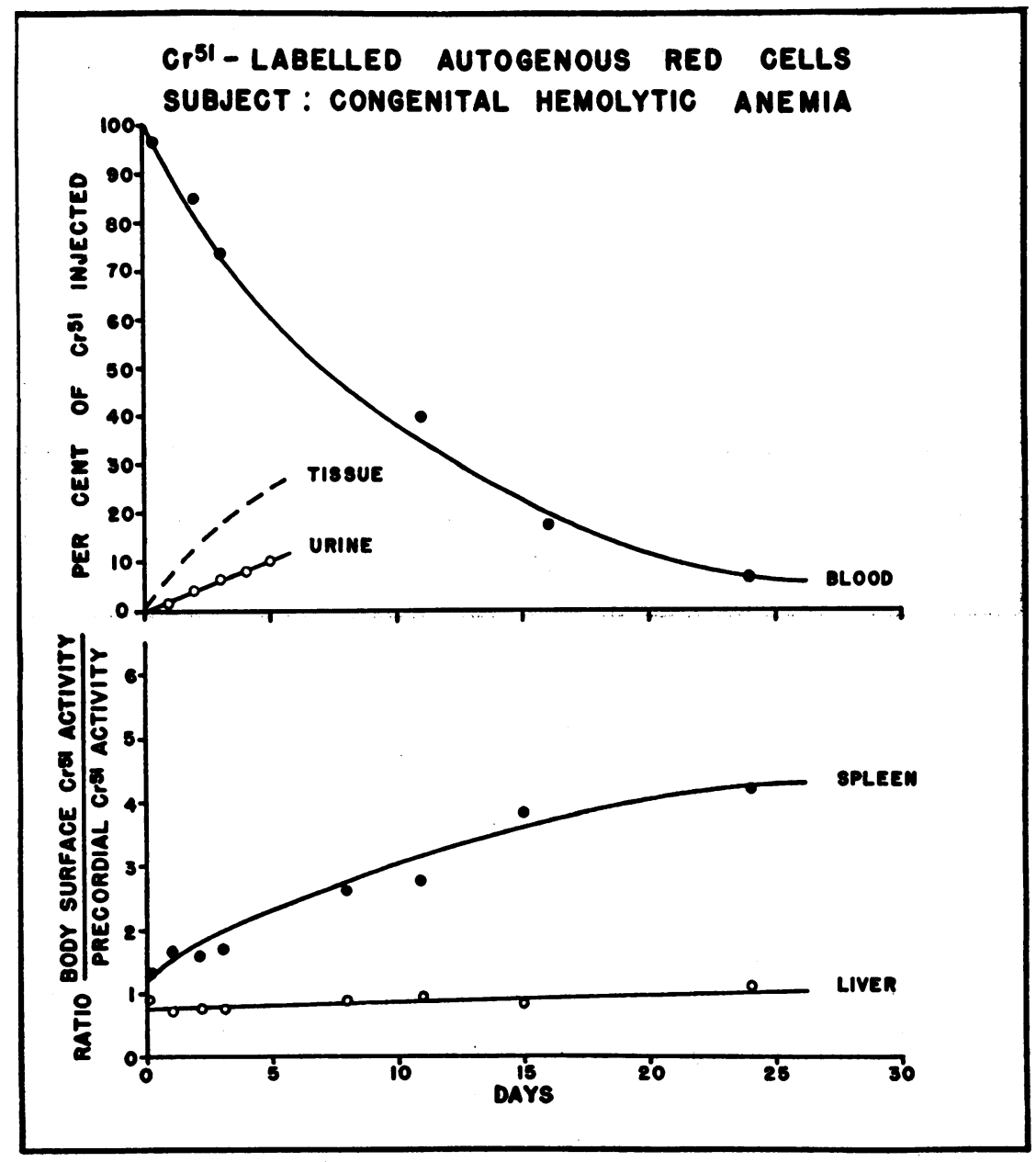

Figure 4A

The increased rate of $\mathrm{Cr}^{\mathrm{s1}}$-labelled red cell destruction in a patient, Case 1 , with moderately severe congenital hemolytic anemia (hereditary spherocytosis) was attended by a predominant uptake of radioactivity over the spleen. Note both the increased splenic activity at zero-time and the manner in which $\mathrm{Cr}^{\mathrm{b}_{1}}$ is progressively deposited in the spleen in proportion to its removal from the blood stream. 


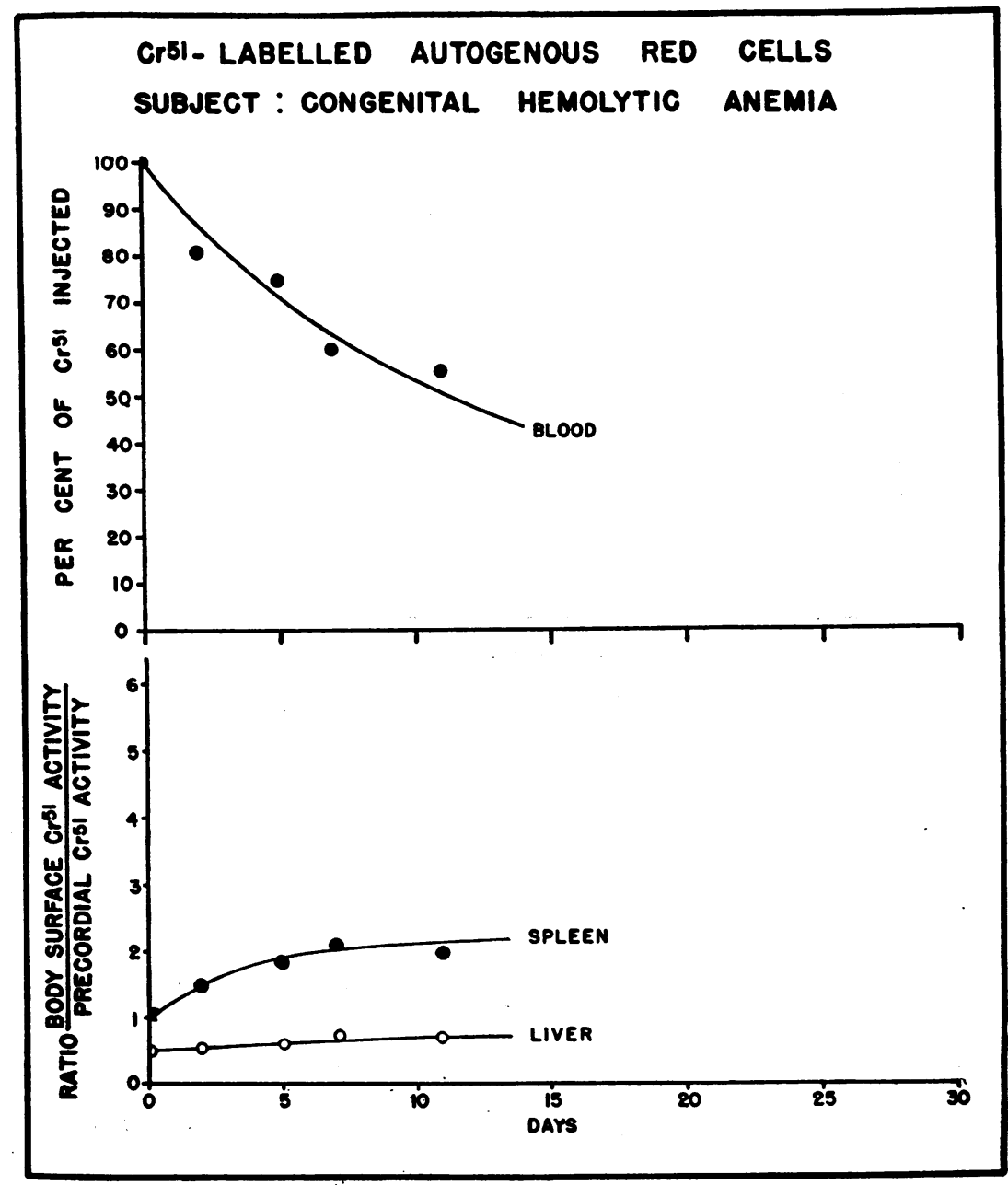

Figure 4B

The rate of red cell destruction in this patient, Case 2, with mild congenital hemolytic anemia (hereditary spherocytosis) was less rapid than in Case 1. There was also a less pronounced but still predominant uptake of $\mathrm{Cr}^{\mathbf{s}_{1}}$ by the spleen.

\section{RESULTS}

General observations on red cell survival and calculated daily hemoglobin production

The half-survival of $\mathrm{Cr}^{51}$-labelled autogenous red cells given 3 normal subjects was $33 \pm 2$ days (mean: 32.8 ). The red cell survival curves were slightly concave when the uncorrected data were charted on rectilinear graph paper. When these data were corrected for an in vivo "elution" of $\mathrm{Cr}^{51}$ from $\mathrm{Cr}^{51}$-labelled red cells of 1 per cent daily as suggested by Ebaugh, Emerson, and Ross (12), the normal red cell survival data formed a straight line on rectilinear graph paper, indicating red cell destruction by senescence resulting in a mean cell life span of 112 days. On the other hand in all but 1 of the 11 patients with hemolytic anemias the blood $\mathrm{Cr}^{51}$ data uncorrected for elution formed a straight line when plotted against time on semilogarithmic graph paper. Red cell destruction in these subjects was thus "exponential" or random in nature indicating that senescence did not detectably participate in the process, presumably since the rapidity of the random process (or processes) minimized cell death by aging. The rates of red cell destruction were thus calculated directly from the slopes of the red cell survival curves and are given in Table I. The correction 
factor for the "elution" of $\mathrm{Cr}^{\mathrm{s1}}$ from normal red cells was again employed, although recognizing that this rate may actually differ for diseased red cells. In one anemic patient, Case 9, despite stable peripheral blood levels during the observation period, the $\mathrm{Cr}^{51}$-labelled red cell survival data corrected for elution produced a straight line on neither rectilinear nor semilogarithmic graph paper. This survival curve presumably reflected a mixture of accelerated senescence and of random destruction. The rate of red cell destruction in Case 9 was estimated by a simple method for determining the mean red cell life span based on the concept of total red cell days (13).

The rates of hemoglobin production shown in
Table I were determined in those 10 anemic subjects manifesting random red cell destruction as the product of the calculated rate of red cell destruction and the mean total circulating hemoglobin level during the period of observation. In the normal subjects and in one anemic subject, Case 9, with a mixed hemolytic process hemoglobin production was calculated on the basis of the estimated mean red cell lifespan.

Fate of $\mathrm{Cr}^{51}$ derived from labelled red cells, hemoglobin, and chromic chloride

Observations on one of the normal subjects who received $\mathrm{Cr}^{51}$-labelled autogenous red cells are pre-

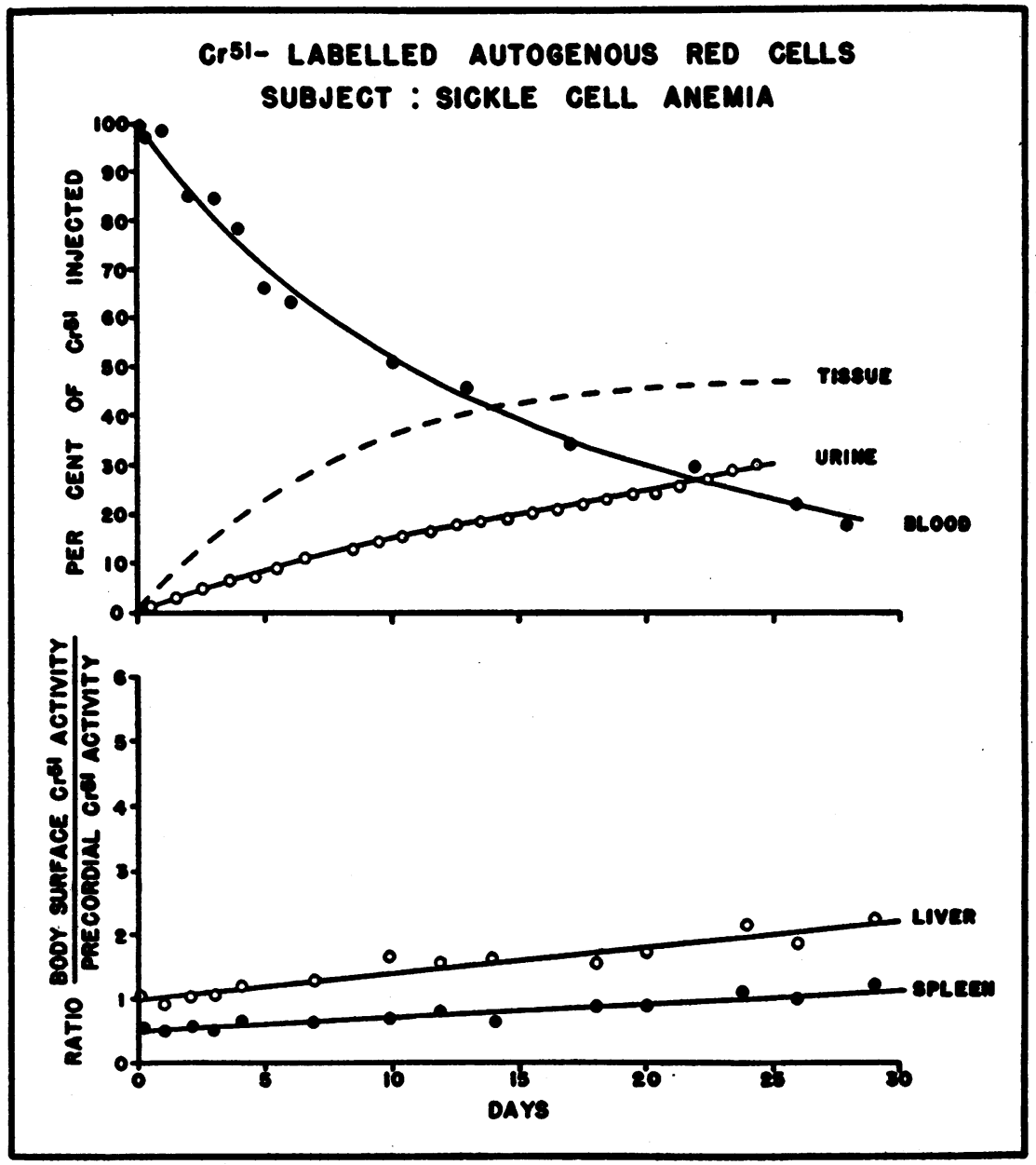

Figure 5A

The $\mathrm{Cr}^{\text {sa }}$-labelled red cells of a patient, Case 3, with moderately severe sickle cell anemia were removed from the circulation in an "exponential" fashion and showed a half-survival time of $\mathbf{1 1 . 2}$ days. There was a moderate increase in radioactivity over the liver but not over the splenic area. 


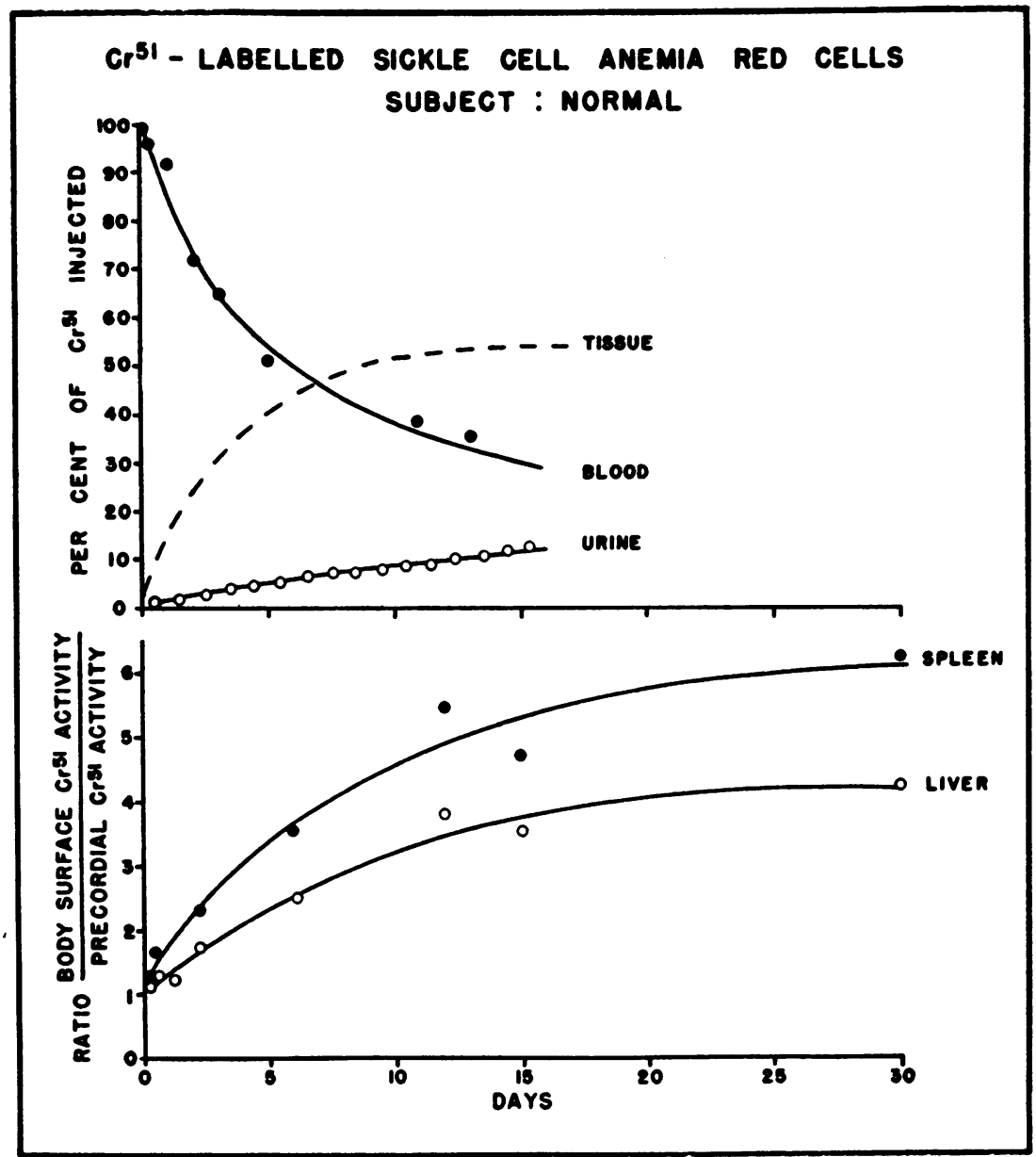

Figure 5B

The simultaneously observed survival of red cells from Case 3 in a normal compatible recipient was appreciably shorter with a half-survival time of 6.0 days. This was associated with high levels of radioactivity over both spleen and liver. Note also the smaller excretion of $\mathrm{Cr}^{\text {sa }}$ in the urine of this subject.

sented in Figure 1. In the upper portion slow accumulation of $\mathrm{Cr}^{51}$ in the tissues is evident, amounting to about 60 per cent of the $\mathrm{Cr}^{51}$ removed from the circulation at the red cell halfsurvival time. A high, transient $\mathrm{Cr}^{51}$ excretion in the urine followed for 1 to 2 days the injection of unwashed $\mathrm{Cr}^{51}$-labelled red cells in subjects not presented here, whether or not a reducing substance such as ascorbic acid had been added to the sample of whole blood prior to injection; however, no such early hyperexcretion of $\mathrm{Cr}^{51}$ was evident in the normal subjects who received washed $\mathrm{Cr}^{51}$ labelled red cells. The radioactivity over the livers as well as over the spleens of normal subjects 20 minutes after the injection of $\mathrm{Cr}^{51}$-labelled red cells ranged from 60 to 80 per cent of that over the precordium; and even after 30 days this ratio increased little. The lower portion of Figure 1 depicts the slow minimal increase in relative radioactivity occurring almost equally over liver and spleen thereafter.

Each of three other normal subjects (not listed in Table I) was given $1 \mathrm{gm}$. of $\mathrm{Cr}^{51}$-labelled autogenous hemoglobin injected intravenously over a period of 2 or 3 minutes. This produced no hemoglobinuria or hemosiderinuria and led to zero-time plasma hemoglobin levels which ranged from 30 to $40 \mathrm{mg}$. per cent. Hemoglobin, as determined colorimetrically, was cleared from the plasma in an exponential fashion with a half-disap- 
pearance time of from 1.5 to 2 hours. In contrast, both the whole blood and the plasma $\mathrm{Cr}^{51}$ activity disappeared at a slower rate with a halfdisappearance time of about 3 hours and a continually slowing rate of disappearance thereafter (Figure 2). Although this in vivo "separation" of chromium from hemoglobin began shortly after injection, $\mathrm{Cr}^{51}$-labelled hemoglobin incubated at $37^{\circ} \mathrm{C}$. in vitro in the presence of serum retained its radioactivity for 24 hours, as determined by electrophoresis and radioautography. ${ }^{7}$ As depicted

${ }^{7}$ In a similar study $\mathrm{Cr}^{61}$ initially bound to gamma globulin (Cohn fraction II-1, 2) migrated electrophoretically with the albumin and alpha globulin after 24 hours' incubation of the labelled gamma globulin with normal plasma. in Figure 2, after 24 hours in vivo 60 per cent, and by 8 days 75 per cent of the $\mathrm{Cr}^{51}$ removed from the blood stream was deposited in the body tissues. The highest level of body radioactivity appeared over the liver and approached a maximum within 6 hours; a parallel but lesser rise in radioactivity appeared over the spleen. Following the injection of $1 \mathrm{gm}$. of $\mathrm{Cr}^{51}$-labelled hemoglobin into a splenectomized patient the rate of disappearance of $\mathrm{Cr}^{51}$ and of hemoglobin from the plasma was similar, but there was no increase in radioactivity over the "spleen" area. The maximal hepatic activity in this patient, as in normal subjects, approximated 3 times that of the precordium. Twenty-four hours after the injection of $\mathrm{Cr}^{51}$ -

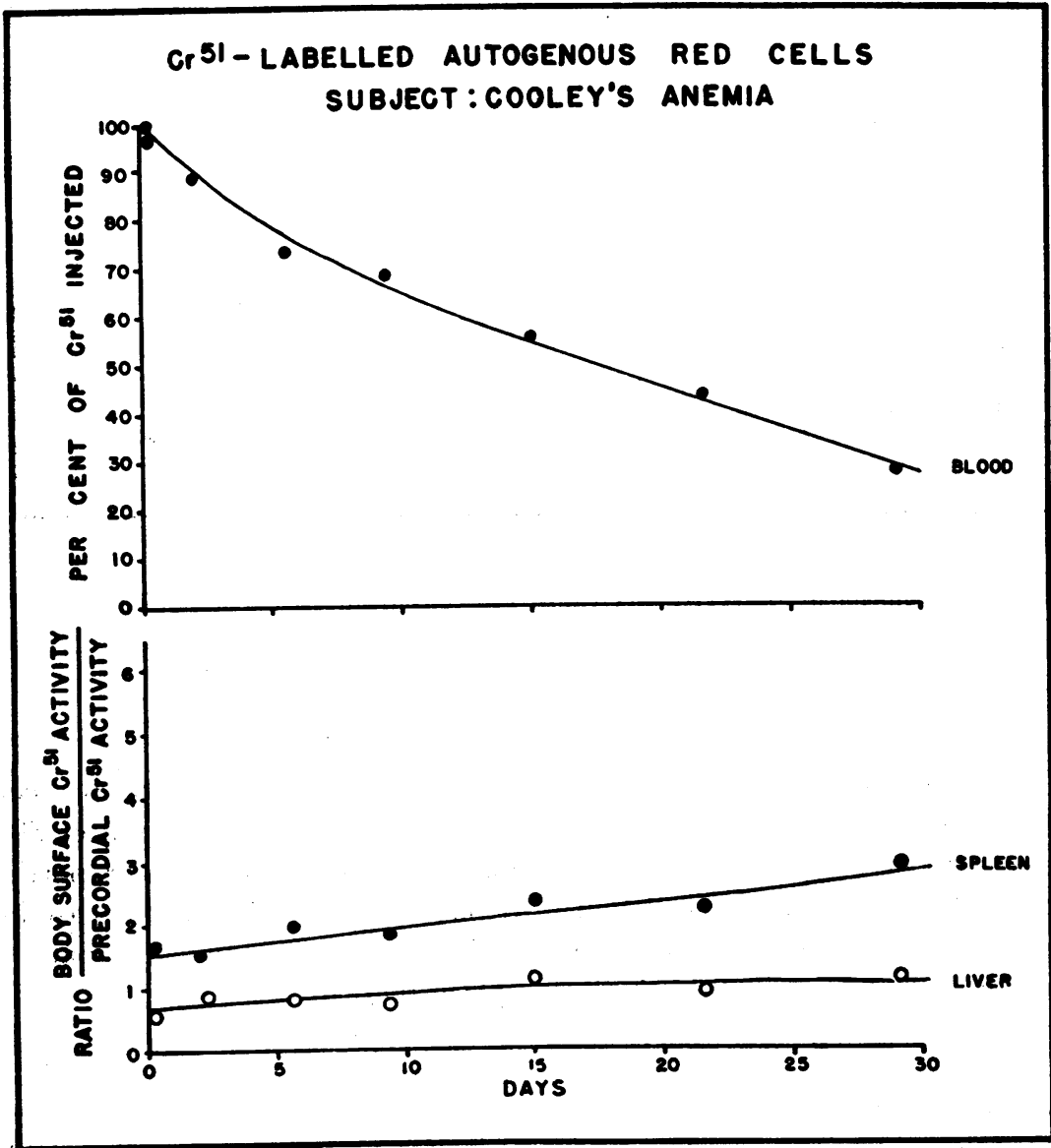

FIGURE 6

The red cell half-survival time in this patient, Case 4, with Cooley's anemia (thalassemia major) was 16.5 days. The high initial relative radioactivity over the patient's large spleen indicates a large vascular organ. The subsequent progressive increase of radioactivity over the patient's spleen mirrored the $\mathrm{Cr}^{\mathrm{OL}}$-labelled red cell survival curve and indicates progressive red cell sequestration by the spleen. 


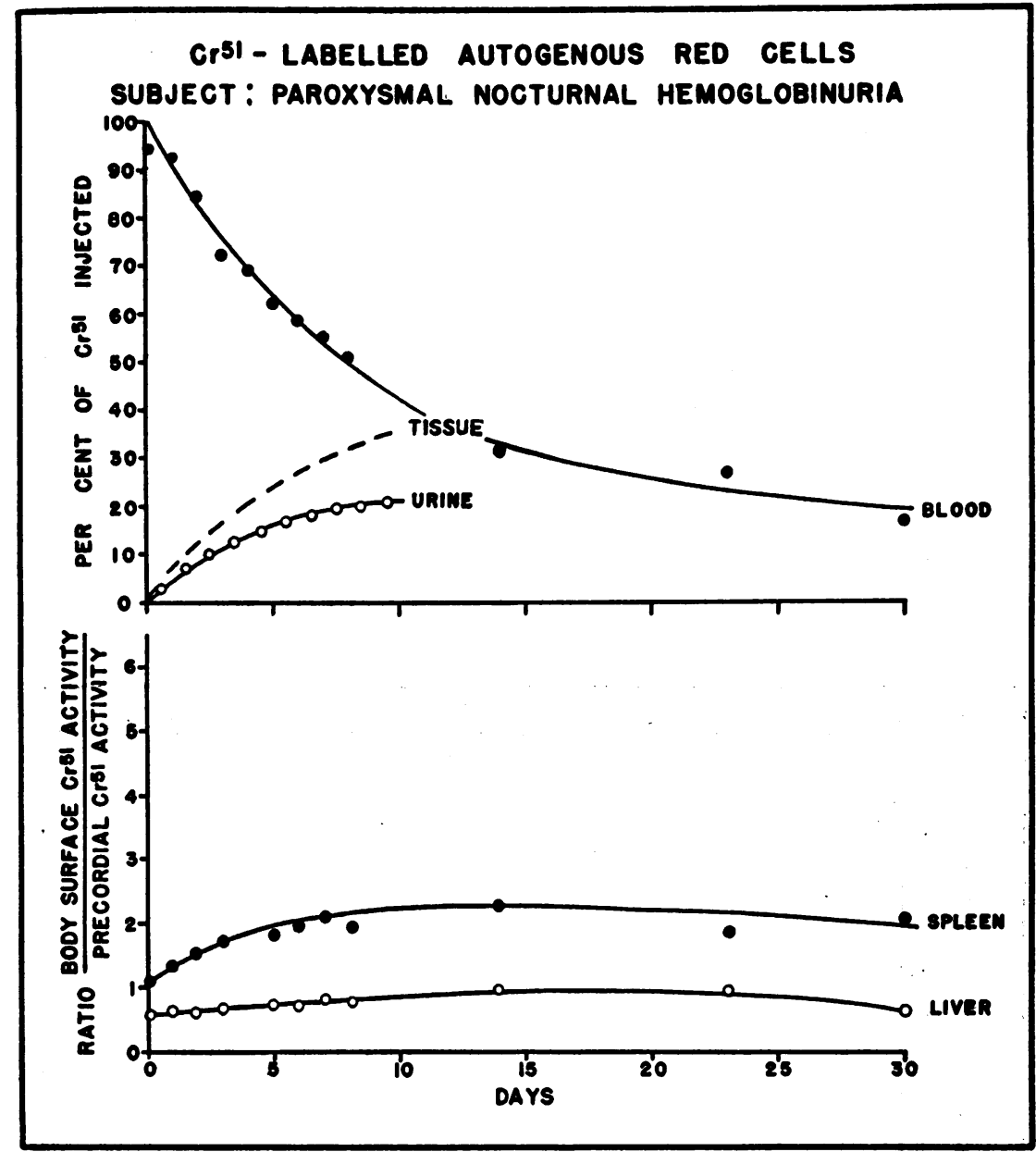

Figure 7A

The early rapid phase of red cell destruction depicted in this patient, Case 5, with paroxysmal nocturnal hemoglobinuria and splenomegaly presumably represented destruction of the patient's own red cells with a half-survival estimated at about 7.2 days. The late slow phase was presumed to represent disappearance of the normal previously transfused red cells which were estimated to constitute 30 per cent of those in circulation at the time of labelling with chromium. An increased accumulation of $\mathrm{Cr}^{\mathrm{s1}}$ by the patient's enlarged spleen was observed. This uptake was about half that of a patient with hereditary spherocytic anemia, Case 1, whose red cell survival was similar (Figure 4A).

labelled autogenous hemoglobin solution into a $\mathrm{dog}$, the concentrations of radioactive chromium in the liver and spleen of the sacrificed animal were similar and greatly exceeded those of the lungs, lymph nodes and bone marrow. An intermediate concentration of radioactivity was found in the kidney. The major amount of chromium was thus present in the heaviest organ, the liver.

The fate of a reduction product of sodium chromate, trivalent cationic chromium, was in- vestigated in two normal subjects. In the first subject, $\mathrm{Cr}^{51} \mathrm{Cl}_{3}$ was injected in saline intravenously; and in a second subject after preliminary incubation with the recipient's serum at $37^{\circ} \mathrm{C}$. for one hour. In both, most of the $\mathrm{Cr}^{51}$ was promptly removed from the blood stream and in large part excreted in the urine. The half-disappearance time of $\mathrm{Cr}^{51}$ from the blood stream was about 15 minutes in each instance. In the first subject, as shown in Figure 3, a slight progressive hepatic 
uptake of $\mathrm{Cr}^{51}$ occurred. In the second, a hepatic uptake of two times that of the precordium was observed at the end of 24 hours. In neither case was significant splenic radioactivity noted.

\section{Patients with intracorpuscular defects}

Congenital hemolytic anemia. Studies of a patient, Case 1, with moderately severe congenital hemolytic anemia (hereditary spherocytosis) demonstrated an abbreviated exponential red cell survival curve in which half the cells were removed in 8.0 days (Figure 4A). Radioactivity over the moderately enlarged spleen was 124 per cent of that of the precordium at zero-time and the relative splenic radioactivity increased steadily in general proportion to the decline in blood activity to reach about 400 per cent of that of the precordium after 25 days. Hepatic $\mathrm{Cr}^{51}$ activity remained low. No hemoglobin or $\mathrm{Cr}^{51}$ appeared in the patient's plasma.

A second patient, Case 2, with hereditary spherocytosis and anemia of mild intensity, showed similar but less pronounced findings (Figure 4B). The red cell half-survival in this patient was 11.9 days. At that time the relative splenic radioactivity was over twice that of the precordium. Again, the initial radioactivity over the patient's enlarged spleen exceeded that of the normal subjects and that over the liver remained low. A similar increase of $\mathrm{Cr}^{51}$ occurred over the spleen of a normal subject of compatible blood group who received labelled red cells from Case 2. The

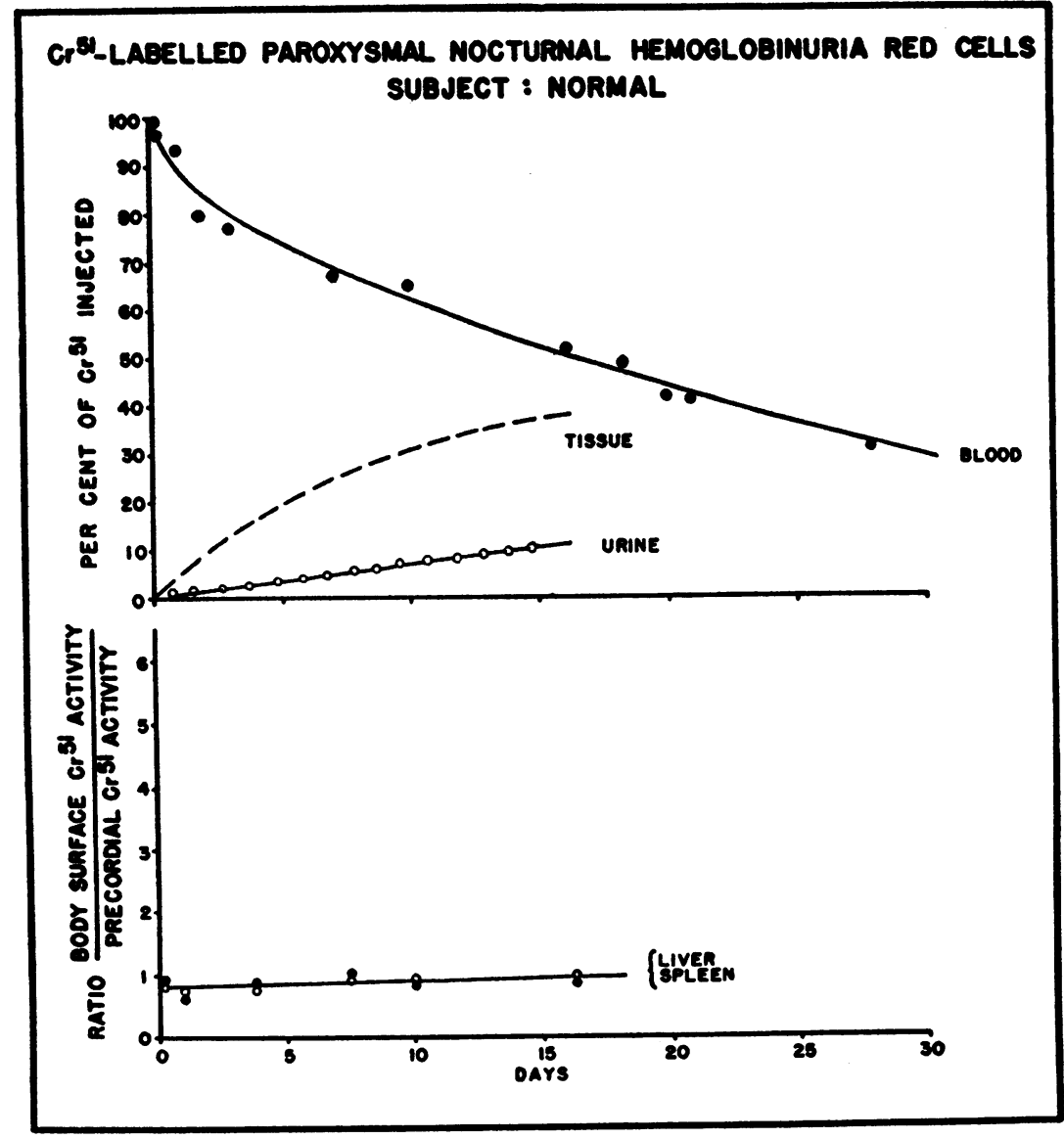

FIGURE 7B

Injection of the red cells of the same patient, Case 5, with paroxysmal nocturnal hemoglobinuria into a normal compatible recipient resulted in a longer red cell half-survival time of these cells, 16.0 days. As indicated above no definite $\mathrm{Cr}^{31}$ uptake was evident over either liver or spleen. 


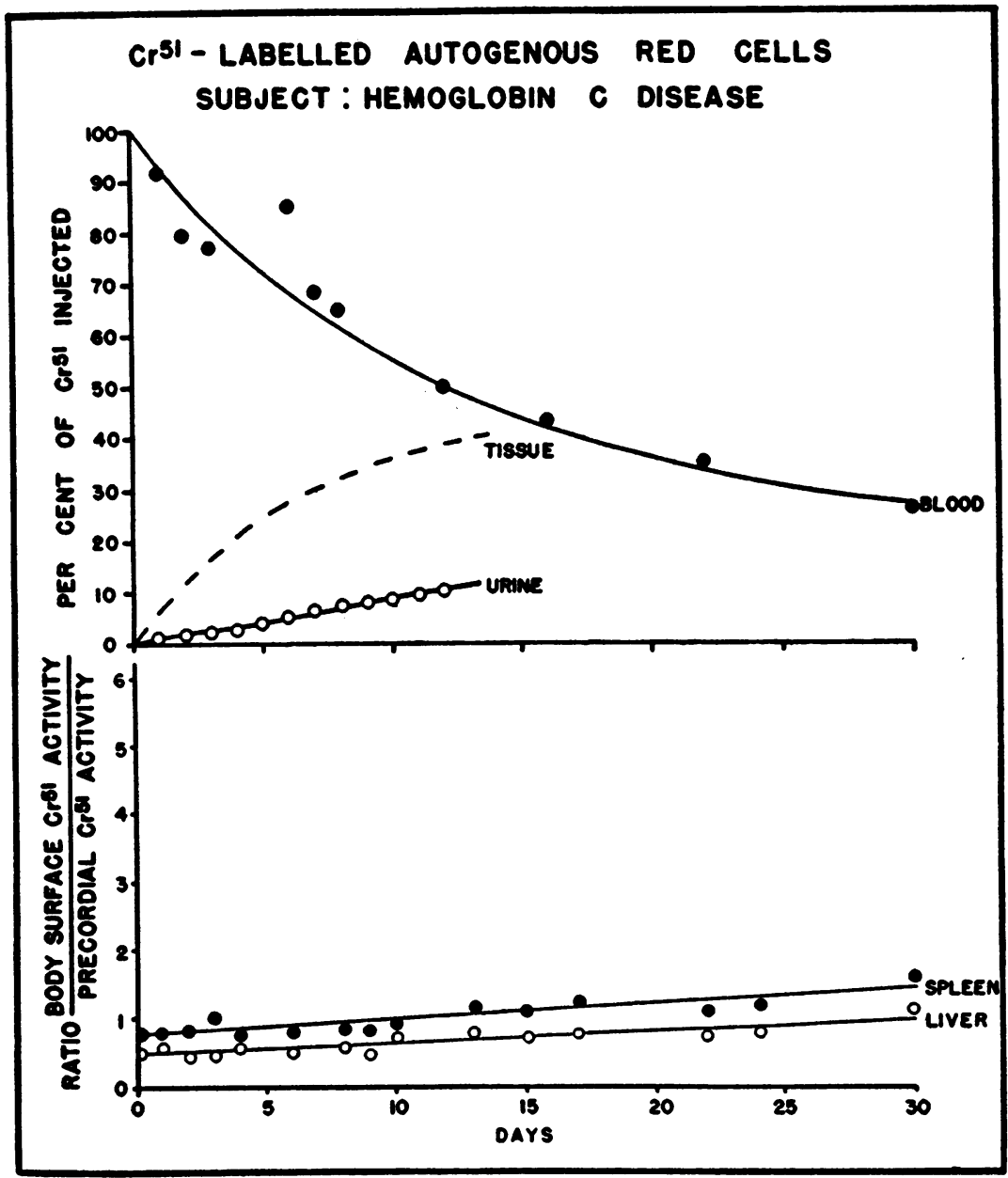

Frgure 8

The moderate increase in autogenous red cell destruction in a patient, Case 6, with homozygous hemoglobin $\mathrm{C}$ disease was associated with only a slight rise in radioactivity over spleen and liver. $\mathrm{The}^{\mathrm{Cu}}$ accumulation in the spleen probably falls within normal limits.

patient's red cells were destroyed more rapidly in the normal recipient than in the patient himself.

Sickle cell anemia. The fate of the red cells of a patient, Case 3 , with sickle cell anemia is depicted in Figure 5A. Half of these red cells were removed from the blood stream in 11.2 days at which time about 70 per cent of the derived $\mathrm{Cr}^{51}$ ( 35 per cent of that injected) was retained in the body. A moderate gradual increase in hepatic $\mathrm{Cr}^{51}$ uptake accompanied the disappearance of $\mathrm{Cr}^{51}$ from the blood, whereas "splenic" radioactivity was initially abnormally low and increased little thereafter. A second patient with sickle cell anemia, not reported here, showed almost identical find- ings. Simultaneously with the study depicted in Figure 5A, a portion of the labelled red cells from Case 3 were injected into a normal compatible recipient. The rate of destruction of the sickle cell anemia red cells was distinctly greater than in the patient herself. Their half-survival time was 6.0 days, and at that time a larger fraction, over 80 per cent, of the derived $\mathrm{Cr}^{51}$ was retained in the subject's tissues. In this recipient a pronounced and progressive splenic uptake of $\mathrm{Cr}^{51}$ accompanied a moderately heavy increase in hepatic radioactivity. In neither subject did $\mathrm{Cr}^{51}$ appear in the plasma.

Cooley's anemia. The half-survival time of the autogenous labelled red cells of a patient, Case 4. 
with Cooley's anemia (thalassemia major) was 16.5 days (Figure 6 ). There was, accompanying this, a moderate increase in splenic radioactivity. beyond the initially elevated relative radioactivity over the patient's moderately large spleen.

Paroxysmal nocturnal hemoglobinuria. The half-survival time of the $\mathrm{Cr}^{51}$-labelled autogenous red cells of a patient, Case 5 , with paroxysmal nocturnal hemoglobinuria was 7.2 days (Figure 7A). At the time of labelling approximately 30 per cent of the circulating red cells were normal previously transfused cells. Associated with a period of rapid red cell destruction during the first 15 days after the injection of the labelled mixed red cell population, which presumably represented largely destruction of autogenous red cells, there was a moderate increase in radioactivity over the patient's enlarged spleen. Subsequently a slight decline in relative radioactivity over both spleen and liver attended a progressive slowing of the rate of $\mathrm{Cr}^{51}$ disappearance from the blood presumably associated with the slower destruction of the normal

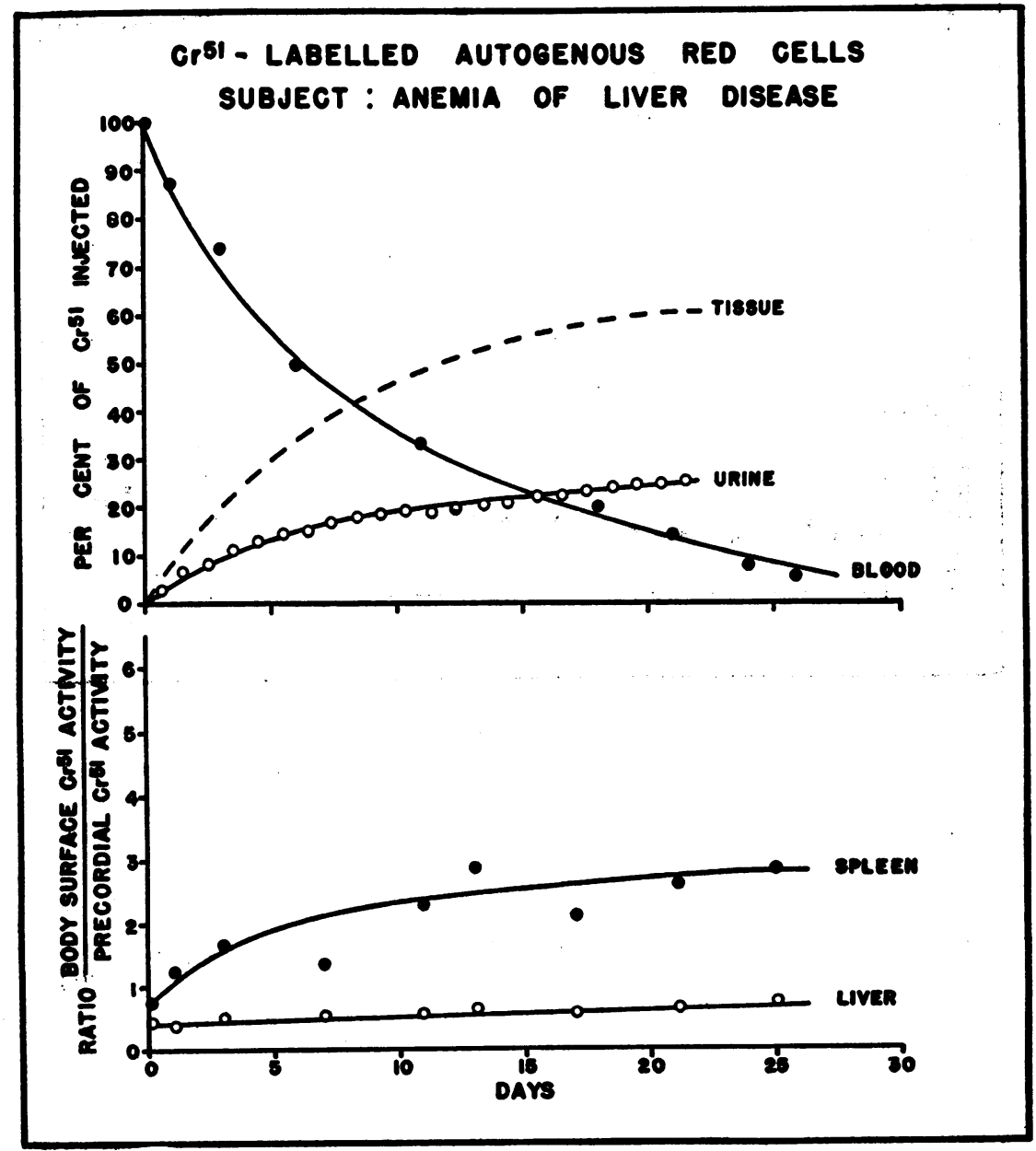

Figure 9

In this patient, Case 7, with severe Laennec's cirrhosis and macrocytic anemia associated with chronic alcoholism the increased rate of disappearance of $\mathrm{Cr}^{\text {b1 }}$ from the blood indicated a moderately severe hemolytic process characteristic of this disease. This was associated with a distinct and progressive accumulation of $\mathrm{Cr}^{\mathrm{ar}}$ over the patient's non-palpable spleen. Note also the initial and sustained abnormally low relative radioactivity over the patient's enlarged liver. This was observed in 3 other patients with cirrhosis, and presumably reflects a reduction in hepatic vascularity. 


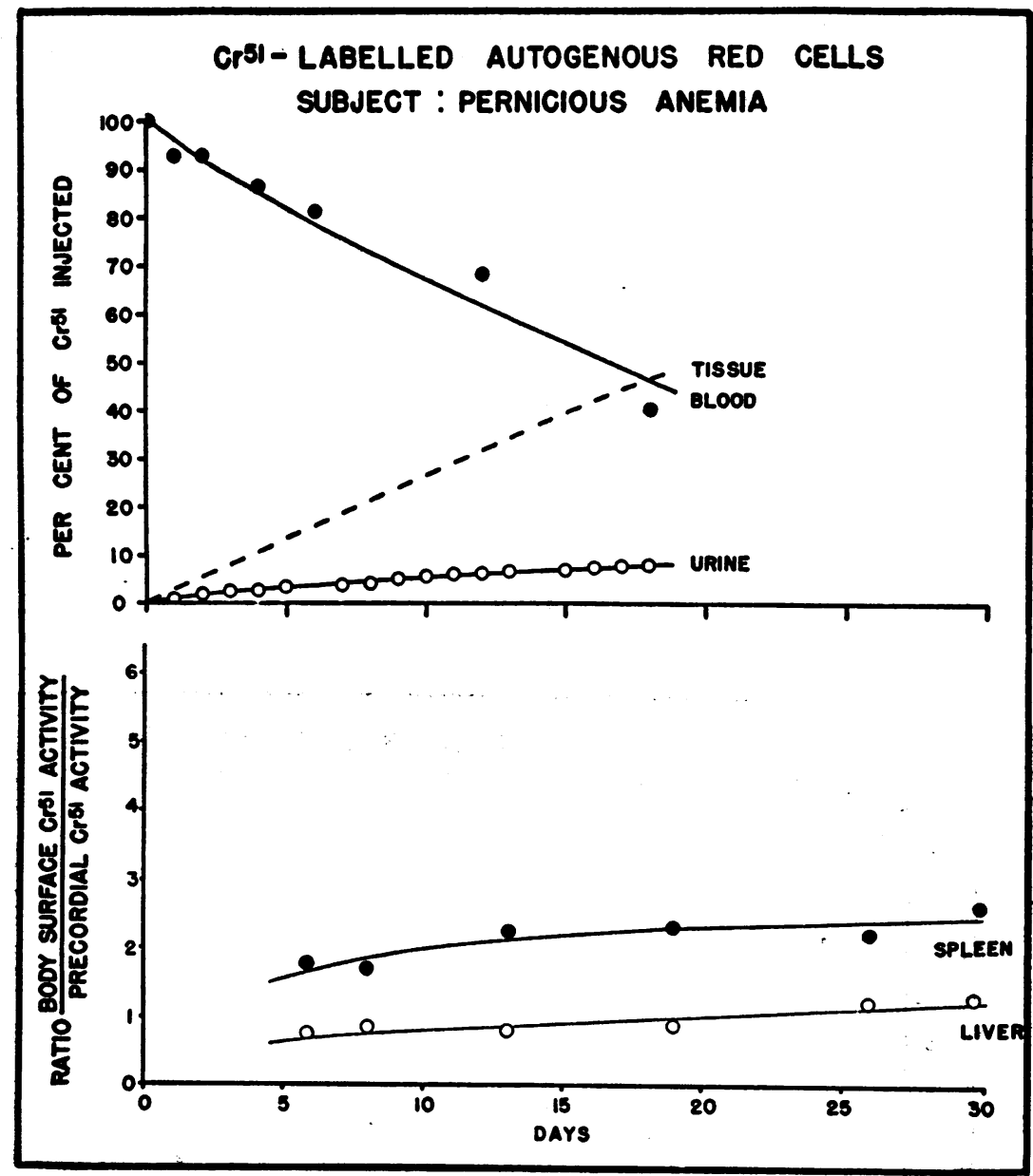

Figure 10

The survival time of the red cells of a patient, Case 8 , with untreated pernicious anemia was moderately reduced. The moderate increase in radioactivity over the patient's non-palpable spleen indicates that the red cells were largely sequestered in that organ.

transfused red cells. One hour after the injection of the labelled red cells 0.6 per cent of the whole blood radioactivity resided in the patient's plasma indicating prompt release of labelled hemoglobin from destroyed red cells. Plasma radioactivity increased to 4.7 per cent of that in the whole blood 1 day later, remained at about 5 per cent for 4 more days and then gradually diminished. The ratio of $\mathrm{Cr}^{51}$ to hemoglobin in the plasma was several times greater than that in the red cells. No plasma $\mathrm{Cr}^{51}$ activity remained at 14 days. In contrast to the deposition of $\mathrm{Cr}^{51}$ from labelled red cells largely sequestered in the spleen, the injection into this patient of $\mathrm{Cr}^{51}$-labelled hemoglobin (not shown in Figure 7A) led to an increase in relative radioac- tivity over both the liver and spleen, with the hepatic uptake predominating slightly. The halfsurvival time of the $\mathrm{Cr}^{51}$ derived from labelled hemoglobin was about three and one-half hours.

Labelled red cells from Case 5 were destroyed less rapidly when transfused into a normal compatible subject (Figure 7B). In this instance the red cell half-survival time was 16.0 rather than 7.2 days, and there was no apparent sequestration by either spleen or liver. Plasma radioactivity was not measured. The possibility, implied by these results, of an exaggerated red cell sequestering action by the patient's clinically somewhat enlarged spleen superimposed upon the underlying intravascular hemolytic process was borne out by the 
subsequent beneficial effect of the surgical removal of a spleen weighing $660 \mathrm{gm}$.

Hemoglobin $C$ disease. A patient, Case 6, with a slight anemia, normal reticulocyte levels, many target cells, and a hemoglobin mobility on filter paper electrophoresis characteristic of hemoglobin $\mathrm{C}$ disease, demonstrated a moderate reduction in the survival of autogenous red cells labelled with $\mathrm{Cr}^{51}$ (Figure 8). Associated with this was a small gradual increase in radioactivity over the spleen and somewhat less over the liver.

\section{Patients with extracorpuscular or mixed defects}

Liver disease. A patient, Case 7, with advanced cirrhosis and macrocytic anemia associated with chronic alcoholism demonstrated the elevated reticulocyte levels (ranging from 8 to 24 per cent), hyperactive erythroid elements in the bone marrow, and increased urobilinogen excretion frequently observed in this disease (14). The red cell halfsurvival time was 6.0 days (Figure 9). There was a moderate progressive increase of radioactivity over the spleen. The $\mathrm{Cr}^{51}$ radioactivity over the liver one-half hour after injection of the labelled red cells was abnormally low, 43 per cent of that over the precordium, and remained low. In 3 other patients with cirrhosis this initial value ranged from 40 to 60 per cent whereas in 6 normal subjects it ranged from 60 to 80 per cent of that over the precordium. Subsequently, $\mathrm{Cr}^{51}$-labelled hemoglobin was injected intravenously into this

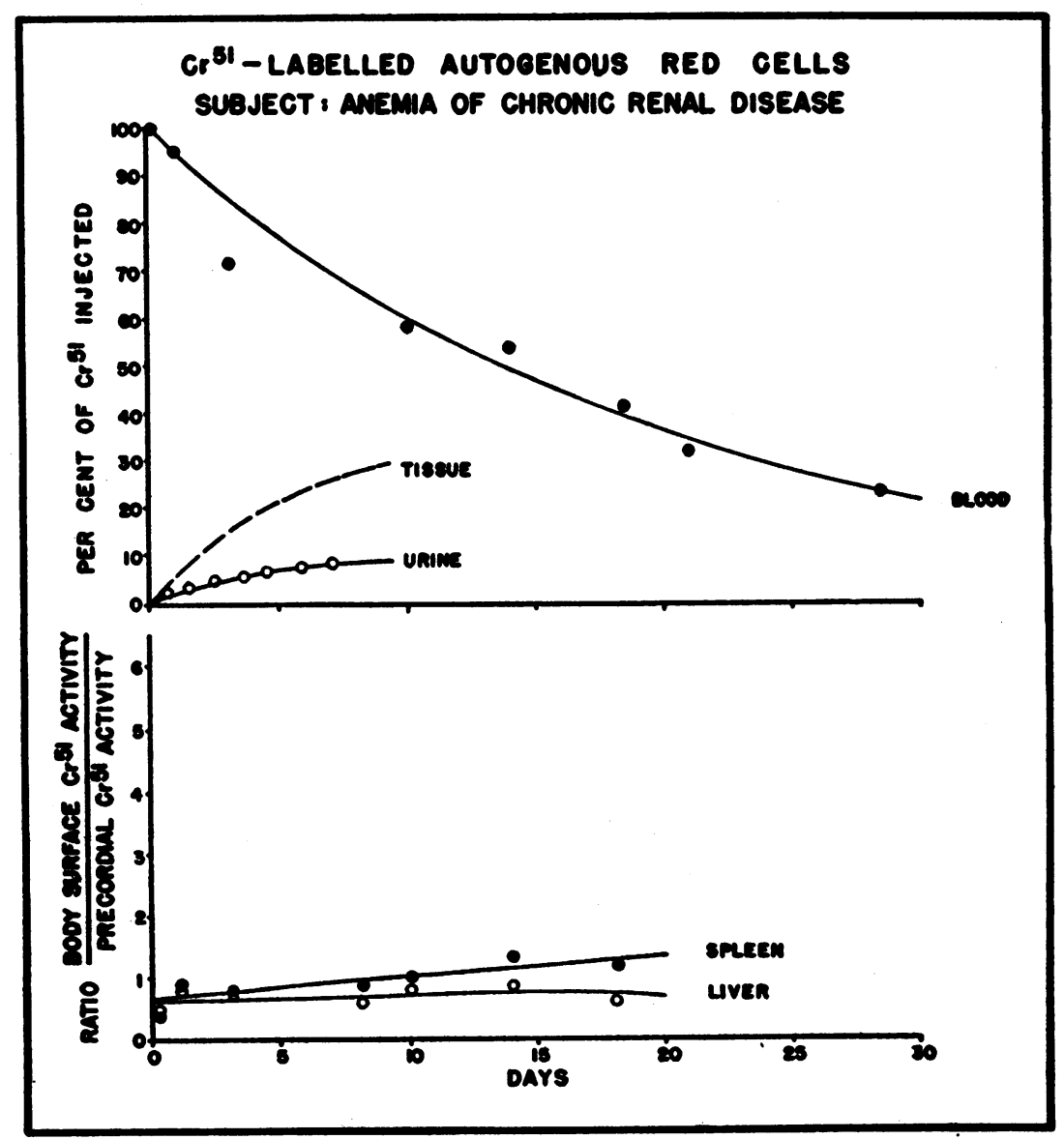

Figure 11

This patient, Case 9, had a fairly severe, stable anemia associated with uremia resulting from chronic pyelonephritis. Despite a $\mathrm{Cr}^{\text {m}}$-labelled red cell half-survival of only 14.4 days, no abnormal accumulation of $\mathrm{Cr}^{\text {nd }}$ occurred in either liver or spleen. 


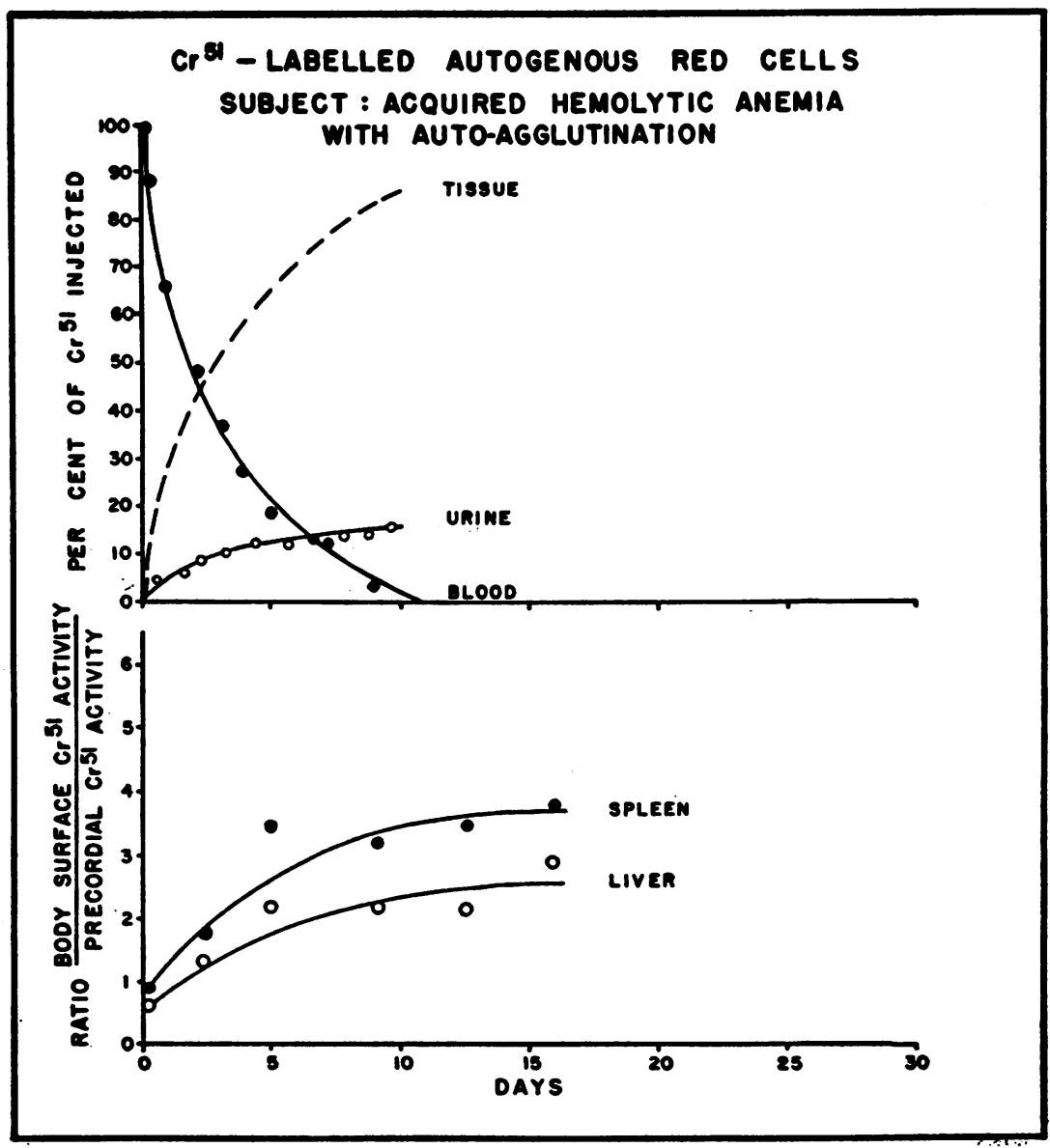

Figure 12A

The extremely rapid disappearance of $\mathrm{Cr}^{\mathrm{sl}}$-labelled red cells in a patient, Case 10 , with a fulminating hemolytic process of unknown etiology was associated with an increased tissue retention of $\mathrm{Cr}^{\text {se }}$ and with high levels of radioactivity over both spleen and liver. Autoagglutination of the red cells in the peripheral blood and hemoglobinemia were present.

subject in divided daily doses calculated to approximate the amount of hemoglobin which had been released from the $\mathrm{Cr}^{51}$-labelled red cells each day. The $\mathrm{Cr}^{51}$ injected in this manner accumulated largely in the patient's liver rather than in the spleen.

Pernicious anemia. The survival time of red cells from patients with untreated pernicious anemia when transfused into normal subjects has been observed by the Ashby technique to be diminished $(15,16)$. A reduced survival of red cells labelled with $\mathrm{Cr}^{51}$ was also observed here in a patient, Case 8, with moderately severe untreated pernicious anemia (Figure 10). A moderate accumulation of $\mathrm{Cr}^{51}$ in the patient's non-palpable spleen was also demonstrated whereas there was no definite uptake of $\mathrm{Cr}^{51}$ by the liver.

Anemia of chronic renal disease. A patient, Case 9, with chronic "stationary" uremia had a sustained, moderately severe, normocytic, normochromic anemia. The reticulocyte levels ranged from 1 to 4 per cent; there were about 5 per cent of "burr cells" in the peripheral blood, and the bone marrow aspirate was normal in appearance and cellular composition. The patient was found to have a reduced survival time of $\mathrm{Cr}^{51}$-labelled autogenous red cells (Figure 11), a frequent finding in uremia (17-19). No increased $\mathrm{Cr}^{51}$ uptake by either liver or spleen attended this process. Despite the shortened red cell survival, as in the 
patient, Case 8, with pernicious anemia, it is interesting that by calculation underproduction was the greater factor in the production of this patient's anemia (Table I).

Acquired hemolytic anemia. A patient, Case 10 , with severe, acute, idiopathic acquired hemolytic anemia of unknown etiology associated initially with hemoglobinemia and hemoglobinuria was studied on two occasions. During the first period of observation spherocytosis, mild autoagglutination of the red cells in the peripheral blood and a positive Coombs test were found, and the patient's reticulocyte levels ranged from 17 to 47 per cent. The half-survival time of the patient's $\mathrm{Cr}^{51}$ labelled autogenous red cells was only 2.3 days. It was estimated that about 29 per cent of her red celts were being destroyed daity and that the daily hemoglobin production averaged $55 \mathrm{gm}$. This remarkably rapid removal of $\mathbf{C r}^{51}$-labelled red cells from the blood stream was accompanied by an increased $\mathrm{Cr}^{51}$ uptake by the spleen and also, to only a slightly lesser extent, by the liver. A repetition of these studies was undertaken 3 weeks later, when auto-agglutination and hemoglobinemia had disappeared, and the signs of hemolysis had lessened. At this time the patient's red cell halfsurvival time had increased to 7.8 days, while the spleen alone accumulated $\mathrm{Cr}^{51}$ (Figure 12B).

A second patient, Case 11, with idiopathic acquired hemolytic anemia exhibited a remarkably constant degree of anemia for several months, with hemoglobin concentrations of from 6.0 to 7.0

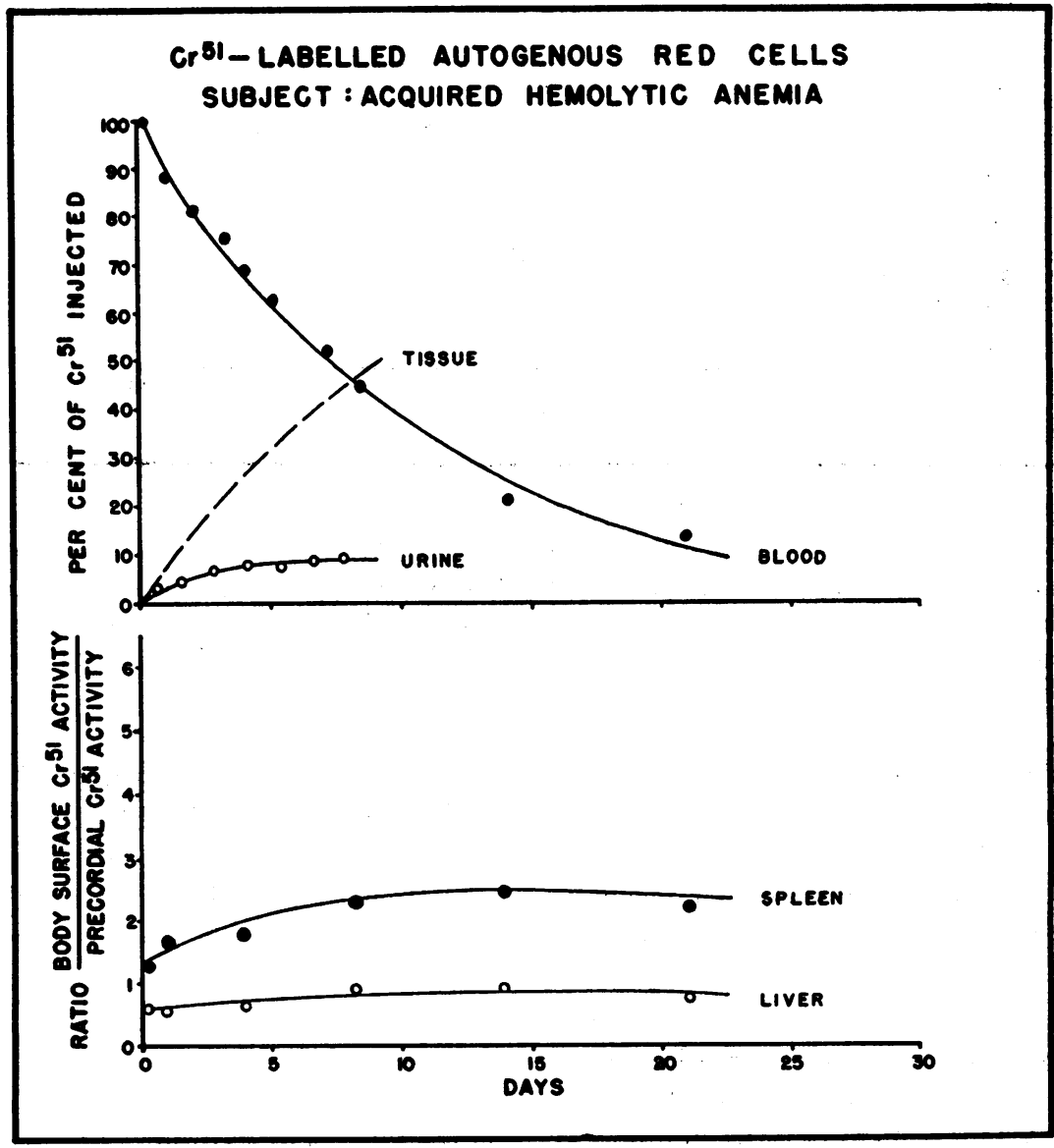

Figure 12B

Repetition 3 weeks later of the injection of $\mathrm{Cr}^{\mathrm{W}}$-labelled autogenous red cells revealed an improved red cell survival at a time when the anemia had diminished. At this time autoagglutination and hemoglobinemia had disappeared, but there was a persistence of red cell sensitization, and less striking evidence of red cell sequestration which was now confined to the spleen. 


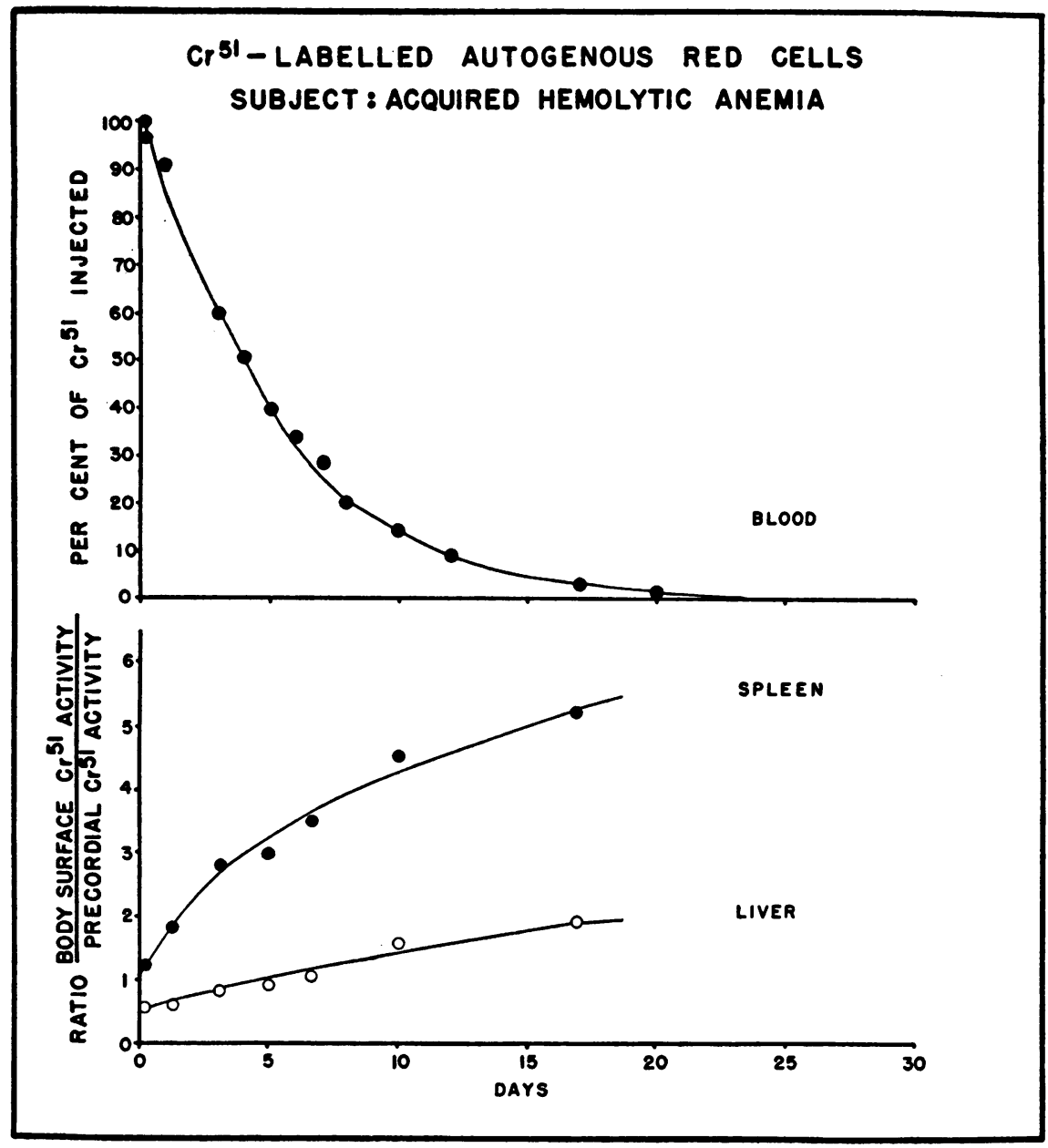

Figure 13

In this patient, Case 11, with moderately severe, stable idiopathic acquired hemolytic anemia associated with evidence of red cell sensitization approximately 20 per cent of the patient's $\mathrm{Cr}^{\omega}$-labelled red cells were removed from the circulation daily. A heavy accumulation of $\mathrm{Cr}^{31}$ in the spleen mirrored the rapid disappearance of $\mathrm{Cr}^{\mathrm{si}}$ from the peripheral blood.

gm. per cent and reticulocyte levels ranging from 19 to 34 per cent. The direct and indirect Coombs tests were persistently positive and slight hemoglobinemia (10 to $15 \mathrm{mg}$. per cent) continued to be present. An estimated 20 per cent of the patient's $\mathrm{Cr}^{51}$-labelled red cells were destroyed daily and high levels of radioactivity accumulated over the slightly enlarged spleen (Figure 13).

\section{DISCUSSION}

$C r^{51}$ in the determination of the sites of red cell sequestration

The observations made on the normal subjects indicate that the excretion and body distribution of $\mathrm{Cr}^{51}$ derived from red cells labelled with $\mathrm{Na}_{2} \mathrm{Cr}^{51} \mathrm{O}_{4}$ differs characteristically from that of $\mathrm{Cr}^{51}$ derived from $\mathrm{Cr}^{51}$-labelled hemoglobin and from saline solutions of $\mathrm{Cr}^{51} \mathrm{Cl}_{3}$. The tissue concentrations in the dog's liver and spleen of $\mathrm{Cr}^{51}$ derived from $\mathrm{Cr}^{51}$-labelled hemoglobin were similar. Thus, the comparatively large liver contained a larger total amount of $\mathrm{Cr}^{51}$. This presumably explains the high radioactivity values found over the livers of normal human subjects who were injected with labelled hemoglobin. A comparable distribution of radioactivity between liver and spleen in rats was observed by Finch and his associates (20) with $\mathrm{Fe}^{59}$-labelled hemoglobin. 


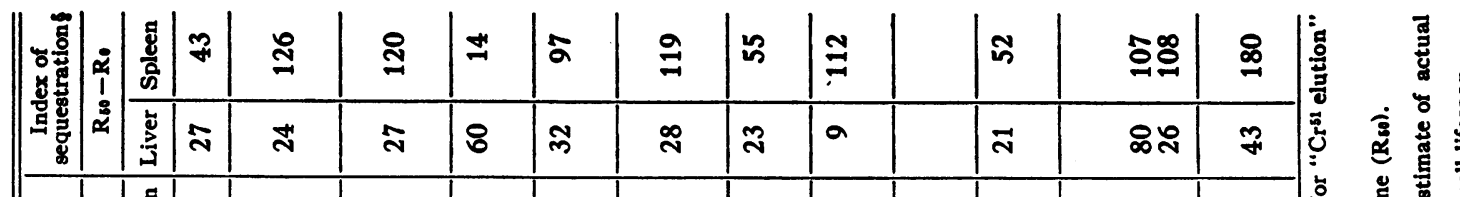

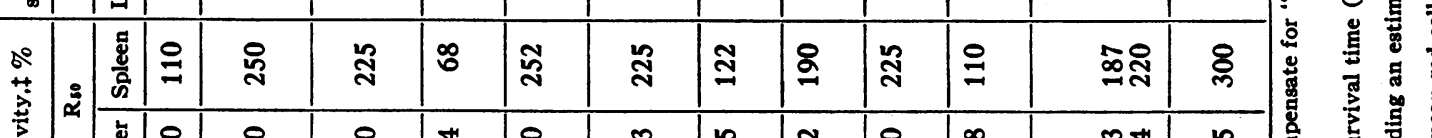

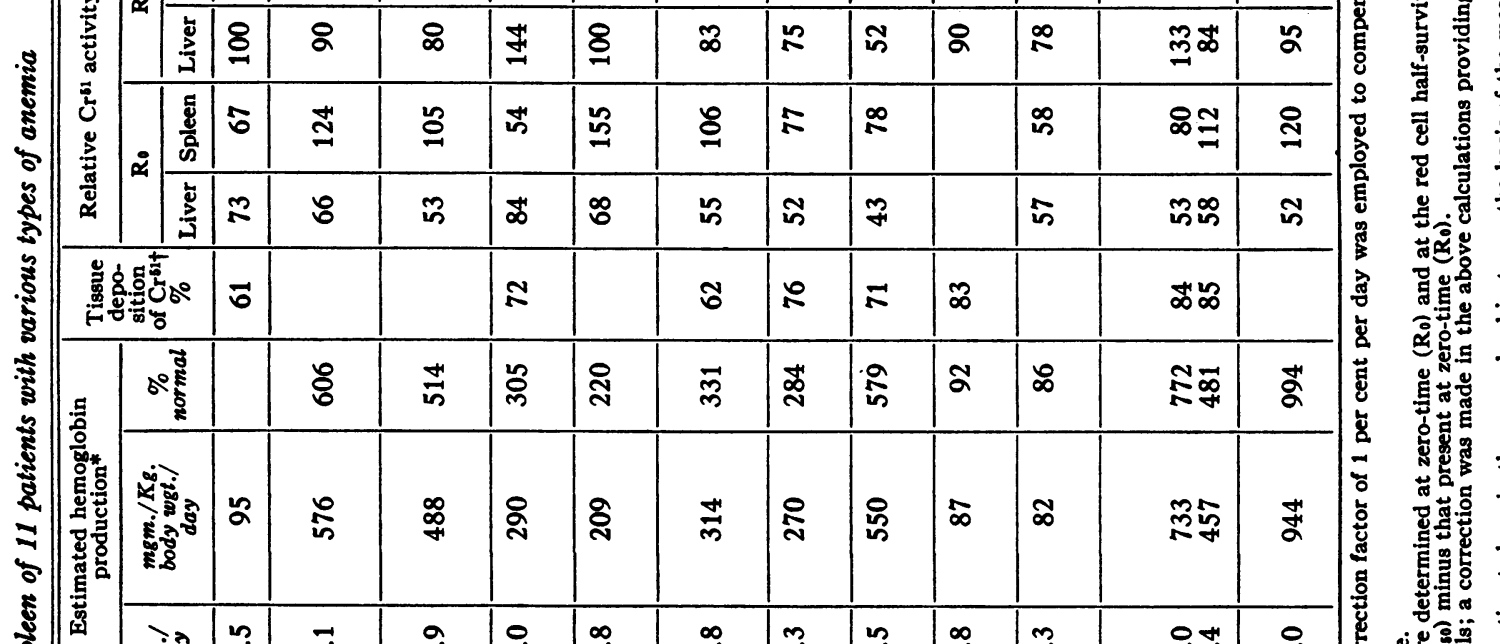

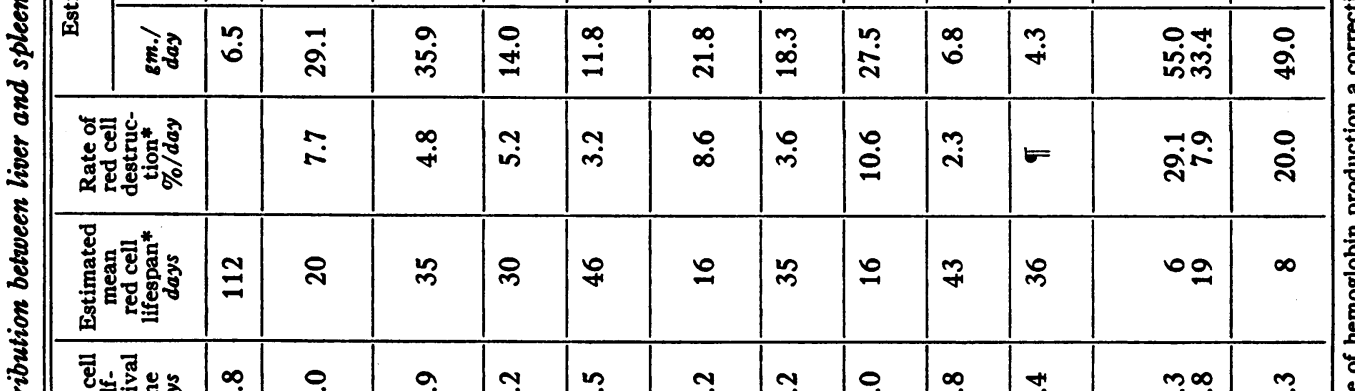

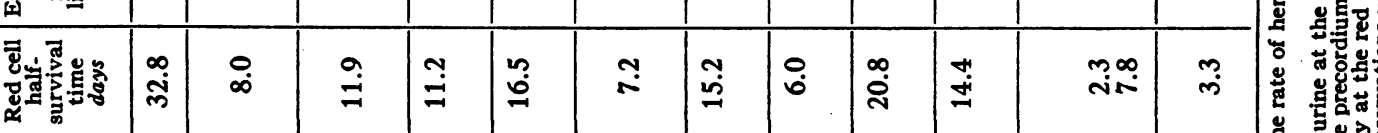

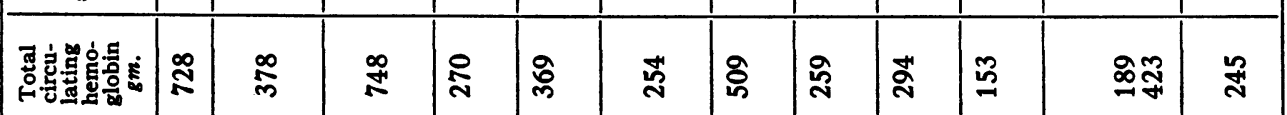

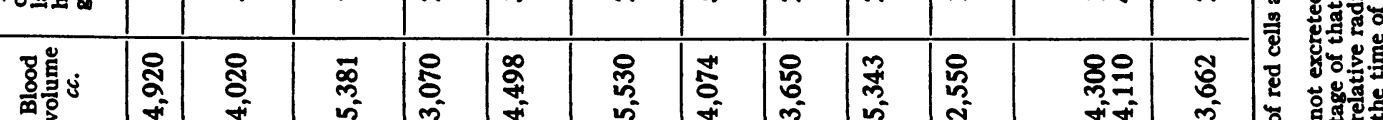

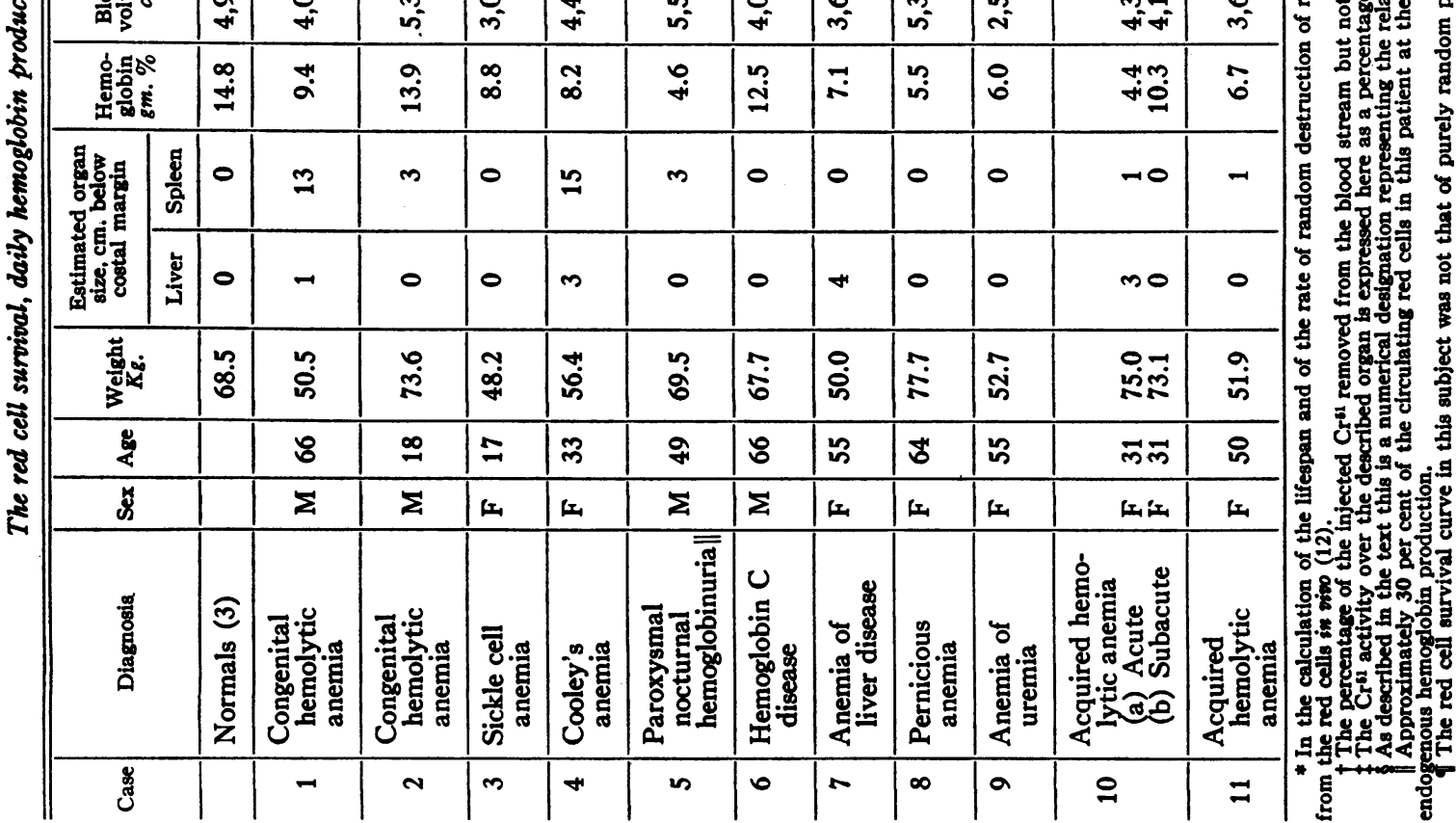


The observed very abrupt clearance of $\mathrm{Cr}^{51} \mathrm{Cl}_{3}$ from the circulation is consistent with the propensity of cationic chromium to form colloidal molecular aggregates above a $\mathrm{pH}$ of 6.0. Here again, the small fraction of $\mathrm{Cr}^{51}$ not excreted was predominantly taken up by the normal liver as determined by body surface counts; the hepatic uptake of $\mathrm{Cr}^{51}$ was more striking when $\mathrm{Cr}^{51} \mathrm{Cl}_{3}$ had been incubated with serum prior to injection. These results conform with studies of the chromium distribution in rat tissues following the injection of $\mathrm{Cr}^{51} \mathrm{Cl}_{3}$ (21).

Because of the softness of the $x$-ray and gamma ray emissions of $\mathrm{Cr}^{51}$, less than 20 per cent of its radiations penetrate the trunk from a source placed beneath a normal supine subject. Nevertheless, with use of the apparatus described, the quantity of $\mathrm{Cr}^{51}$ generally employed in red cell survival studies (12) is quite adequate for body surface counting. Indeed, the low energy and penetration of these emissions reduces the factor of stray radiation from neighboring organs. An accumulation of local radiation obviously may arise from red cells in transit through or sequestered in a given organ, from released hemoglobin or from $\mathrm{Cr}^{51}$ in some other form deposited in the organ. The gradual accumulation in the urine of $\mathrm{Cr}^{51}$ presumably results in part from its slow elimination from the tissues. On the basis both of direct body counts and of the urinary excretion of $\mathrm{Cr}^{51}$, the rate of loss from the tissue was calculated in 4 subjects who had abruptly sequestered labelled sensitized red cell suspensions (9) to average about 4 per cent per day; the half-life for tissue elimination of $\mathrm{Cr}^{31}$ ranged from 14 to 21 days. Excretion of $\mathrm{Cr}^{51}$ was entirely renal. In no instance was there measurable $\mathrm{Cr}^{51}$ in the stool. Stool $\mathrm{Cr}^{51}$ measurements thus permit the ready detection of a potential error in red cell survival studies: occult intestinal bleeding.

The findings in normal subjects when compared with those in the anemic patients presented above justify certain limited conclusions from body surface counting following injection of red cells labelled with radioactive sodium chromate: (a) A progressive, high splenic uptake of $\mathrm{Cr}^{51}$ represents the splenic sequestration of intact red cells. There appears to be no other way by which $\mathrm{Cr}^{51}$ from labelled red cells can be accumulated preponderantly by the spleen. (b) A high hepatic uptake of $\mathrm{Cr}^{51}$ in the presence of an intact spleen suggests the possibility, although not the certainty, that intravascular hemolysis of labelled red cells has occurred.

That the sequestration of whole red cells by the spleen is indeed detectable by an attendant rise in radioactivity over the spleen was illustrated by Cases 1 and 2. In these patients with congenital hemolytic anemia the splenic $\mathrm{Cr}^{51}$ uptakes mirrored the disappearance of chromium from the blood stream (Figures 4A and 4B). Furthermore, the injection of $\mathrm{Cr}^{51}$-labelled red cells from Case 2 into a normal compatible recipient also led to a high relative radioactivity over the recipient's normal-sized spleen. These observations corroborate the previously established evidence that spherocytes may be selectively retained by either pathologic or normal spleens (1-5). The somewhat longer survival of autogenous $\mathrm{Cr}^{31}$-labelled spherocytes in the patient, Case 2 , with mild hereditary spherocytosis than in a normal compatible recipient may have arisen from the competition for sequestration in the spleen of Case 2 by autogenous unlabelled spherocytes. The moderate hepatic and comparatively low "splenic" uptake of $\mathrm{Cr}^{51}$-labelled autogenous red cells from a patient, Case 3, with sickle cell anemia (Figure 5A) were interpreted as reflecting the splenic atrophy characteristic of this disease $(6,7,22)$, especially because prominent progressive increases in splenic as well as hepatic radioactivity were observed when an aliquot of the sickle cell anemia patient's labelled red cells was transfused into a compatible normal subject (Figure 5B). That the sicklemia red cells survived only half as long in the normal subject as in the patient herself presumably indicates in part the beneficial effect on red cell survival of the "autosplenectomy" characteristic of adult patients with sickle cell anemia. This is in contrast to the short survival time, even of normal red cells, in some children with sicklemia and large spleens observed by Lichtman, Shapiro, Ginsberg, and Watson (23). The considerable hepatic $\mathrm{Cr}^{51}$ uptake noted here also contrasts with the preponderant uptake of $\mathrm{Cr}^{51}$ by the spleen alone in congenital hemolytic anemia. These observations, again, are consistent with previous studies $(1,5-7)$ revealing the hematologic basis for the erythrostasis, thromboses and infarcts 
which early cause severe damage to the spleen and which gradually injure the liver.

In addition to establishing the extent to which $\mathrm{Cr}^{51}$ is accumulated by the liver or spleen, it is possible to discriminate by means of their respective rates of increase between high relative radioactivity due on the one hand to sequestration of labelled red cells and that on the other due to simple organ enlargement with concomitant increase in vascularity. In the former situation local radioactivity necessarily builds up in an organ in approximate proportion to its rate of disappear- ance from the blood. In the latter situation the high initial relative activity over the organ (unless followed at once by rapid accumulation) signifies a large vascular bed rather than red cell sequestration. Thus, the presence of a high initial ratio of spleen $\mathrm{Cr}^{51}$ to precordial $\mathrm{Cr}^{51}$, i.e., greater than about 90 per cent, merely indicates splenomegaly with an attendant increase in perfusing blood and unless the ratio subsequently increases, as for example in Cases 1, 2, 4, 5, 7, 10 and 11, does not necessarily denote sequestration of red cells. A case illustrating this point is presented in Figure

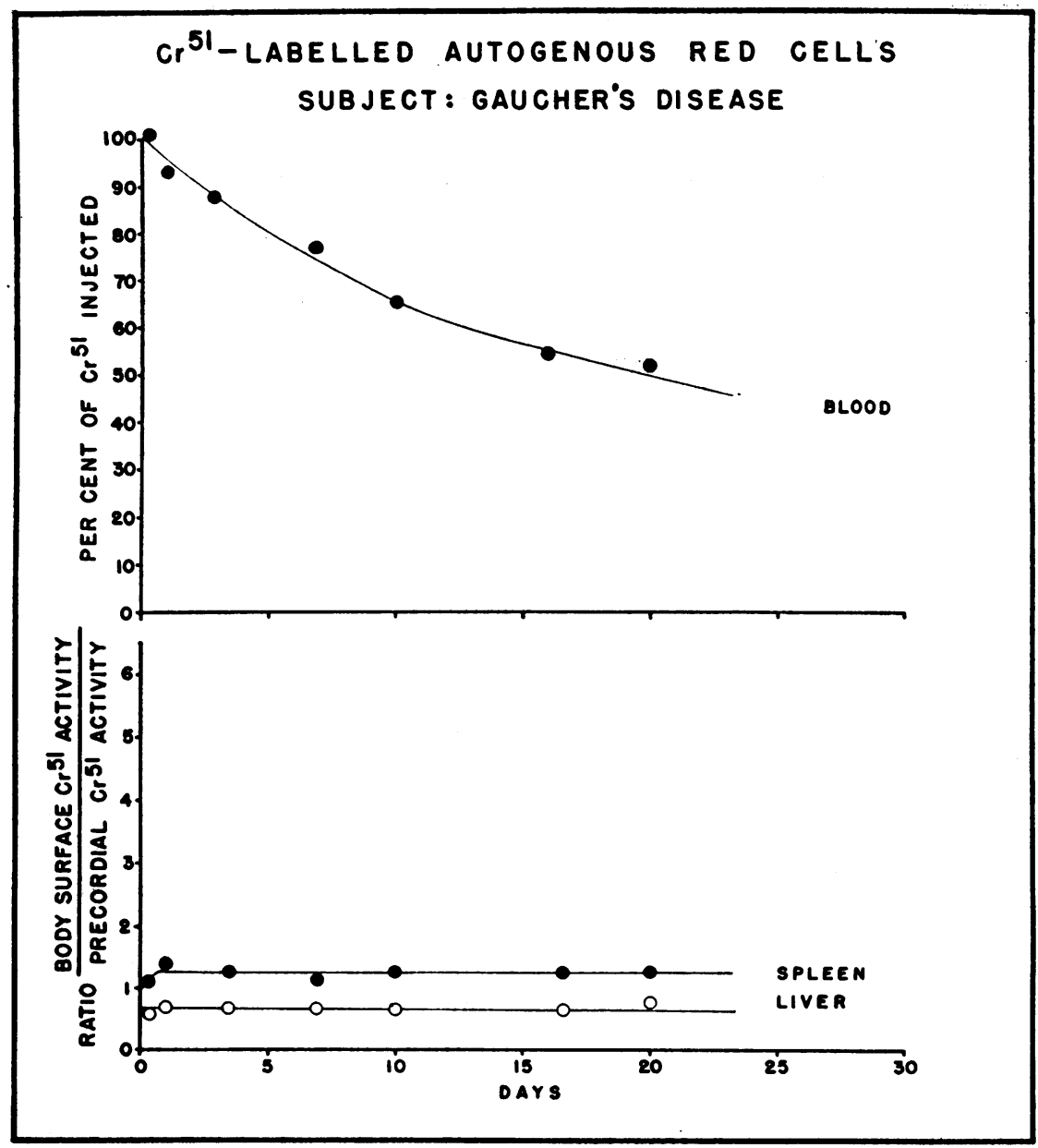

FIGURE 14

This 48-year old Jewish female had splenomegaly and thrombocytopenia on the basis of Gaucher's disease. The patient was not anemic, however, and her red cell survival, as indicated above, was almost normal. Although a high relative radioactivity appeared in the enlarged spleen shortly after the injection of $\mathrm{Cr}^{\text {st }}$-labelled autogenous red cells, there was no subsequent accumulation of $\mathrm{Cr}^{\text {s1 }}$ by the spleen. This pattern of radioactivity reflects the vascular size of the spleen rather than the filtration of red cells. 
14. This patient had splenomegaly on the basis of Gaucher's disease and showed no evidence of hemolysis. Her red cell half-survival time was about 25 days. Within a few hours of the injection of $\mathrm{Cr}^{51}$-labelled autogenous red cells the radioactivity over the spleen was 125 per cent of that over the heart; as blood $\mathrm{Cr}^{51}$ activity declined, however, there was no further uptake of radioactivity by the spleen, suggesting that this large spleen possessed a large vascular bed but did not sequester red cells. Accordingly, $\mathrm{Cr}^{51}$ may sometimes be employed to determine the nature of masses in the left upper quadrant when this is not otherwise possible. It must be pointed out, however, that splenomegaly may exist with little or no increase in relative radioactivity over the spleen. Thus, whereas the initial $\mathrm{Cr}^{51}$ activity over the spleen was elevated in all observed cases of splenomegaly associated with a hemolytic anemia or usually with cirrhosis, this was not so, despite the presence of marked splenomegaly, in one case of chronic lymphatic leukemia; and the $\mathrm{Cr}^{51}$ activity was only slightly increased in one case of agnogenic myeloid metaplasia with massiye splenomegaly. Presumably in these 2 patients splenomegaly reflected non-vascular cellular hyperplasia. The use of $\mathrm{Cr}^{51}$-labelled normal red cells in the anatomic identification of the spleen is thus reliable only in a positive sense, that is, when a high initial relative radioactivity occurs over the suspected area. Conceivably sufficiently large vascular tumors, such as hemangiomata of the liver, might be similarly identified.

Observations (9) reported elsewhere upon the organ distribution of $\mathrm{Cr}^{51}$ and the appearance of hemoglobin in the plasma following injection of $\mathrm{Cr}^{51}$-labelled red cells after exposure to complete or to incomplete antibodies indicate the experimental association of red cell agglutination and deposition in the lung and liver with hemoglobinemia. On the other hand, the association of red cell sensitization, without manifest agglutination, was with splenic sequestration and the absence of hemoglobinemia. On the basis of the plasma hemoglobin levels these processes have classically been distinguished as "intravascular" and "extravascular" hemolysis. The former state has often been taken to indicate the presence of a circulating hemolysin despite the rarity with which hemolysins are actually demonstrable in hemolytic diseases, even in patients (such as Case 10) with fairly striking increases in plasma hemoglobin levels. These experimental observations and those clinical observations reported or referred to here indicate the general tendency of mild or of discrete red cell alterations (as encountered in spherocytes, sensitized cells, and the morphologically peculiar cells encountered in pernicious anemia and in Cooley's anemia) to lead to rather specific sequestration by the spleen presumably due to the refined filtering function of that organ. This is attended by little or no release of hemoglobin into the circulation and may be interpreted as an "extravascular" process. More severe or gross red cell changes, such as agglutination, or discrete cellular changes which may grossly affect blood viscosity, as in sickle cell anemia, lead to a more indiscriminate filtration by the capillaries, especially in the several organs with very large vascular beds: the lungs and liver, as well as the spleen if present and functioning. Such widespread red cell trapping, especially when not in close relation to concentrations of reticulo-endothelial cells, may favor the release of hemoglobin into the plasma and thus simulate the effects of a circulating hemolysin.

It is interesting to note the coexistence of red cell agglutination, a large hepatic uptake of $\mathrm{Cr}^{51}$, and high plasma hemoglobin levels at the time of the first observation on Case 10, a patient at that time with fulminating acquired hemolytic anemia. In Case 11, with an acquired hemolytic anemia of slightly less severity, the red cells were sensitized but not agglutinated, the preponderance of $\mathrm{Cr}^{51}$ activity in the spleen was striking, and there was little rise in the plasma hemoglobin level. Of further interest was the observation that Case 5, the patient with paroxysmal nocturnal hemoglobinuria, manifested an increase in hemoglobinuria following splenectomy despite improvement in the red cell hemoglobin concentration. Later still iron deficiency ensued as evidenced by a fall in mean corpuscular hemoglobin concentration and in the serum iron level. These observations upon Case 5 suggest that following removal of the spleen a greater proportion of the patient's cells were destroyed intravascularly rather than in the spleen with consequent increase in the urinary excretion of iron. 


\section{Technical hazards in the use of Crst}

In the clinical application of the present method, the $\mathrm{Cr}^{51}$-labelling techniques described by others (12) are generally suitable. The uptake of chromate by red cells is highly $\mathrm{pH}$-dependent, diminishing sharply as the $\mathrm{pH}$ exceeds 7.0. Thus, acid anticoagulant solutions, such as ACD solution, are suitable for red cell labelling with sodium chromate. ${ }^{8}$ In addition, trivalent chromium arising from reduction of the chromate by dextrose or by added ascorbic acid is bound by citrate, which in turn inhibits binding by the plasma proteins and by the red cell membranes (9). During the initial moments of the labelling process, chromate enters the red cells so rapidly that a disproportionate "loading" of a small fraction of the cells occurs unless precautions are taken to employ a dilute solution of sodium chromate and to secure its immediate and thorough mixture with the blood sample. Chromate is an oxidant relative to hemoglobin, and methemoglobin appears in detectable quantities when the molecular ratio of chromate to hemoglobin exceeds 0.1 , i.e., above about 22 micrograms of $\mathrm{Cr}^{51}$ or about 70 micrograms of $\mathrm{Na}_{2} \mathrm{Cr}^{51} \mathrm{O}_{4}$ per cubic centimeter of packed red cells. ${ }^{9}$ The glycolysis of red cells, as measured in the Warburg apparatus, was found to be depressed in arithmetic proportion to the chromate concentration of the suspension. A significant depression of red cell glycolysis was demonstrable following the addition of as little as 10 micrograms of $\mathrm{Cr}^{51}$ in the form of sodium chromate per cubic centimeter of packed red cells. Chromated hemoglobin was observed to migrate more rapidly than does normal hemoglobin toward the

8 An exception to this was made in studying the red cells of the patient with paroxysmal nocturnal hemoglobinuria. In order to avoid the acid hemolysis characteristic of this patient's red cells, heparin was employed as an anticoagulant during the labelling procedure.

9 This reaction appears to be a direct chemical oxidation of hemoglobin progressing in proportion to dosage and to time equally well with hemoglobin solutions or with intact red cells. That inactivation of the enzyme normally concerned with the reduction of methemoglobin is not involved was suggested by study of the effect of chromate upon the red cells of a patient with congenital methemoglobinemia, a disease in which this enzyme is believed to be absent or deficient: the rate and extent of conversion of oxyhemoglobin in the patient's red cells to methemoglobin by chromate was the same as in normal red cells. anode of a filter paper electrophoresis cell maintained at a $\mathrm{pH}$ of 8.6 by barbital buffer. Under these conditions, the greater negative charge of the $\mathrm{Cr}^{51}$-labelled hemoglobin induced an increase in the electrophoretic mobility of hemoglobin of over 15 per cent. All of these observations stress the chemical alterations brought about by the $\mathrm{Cr}^{51}$. labelling procedure, and urge that care be taken to label the red cell aliquots evenly and with $\mathrm{Na}_{2} \mathrm{Cr}^{51} \mathrm{O}_{4}$ of high specific radioactivity.

Ordinarily there is no apparent necessity for washing the patient's red cells prior to re-injection or for measuring the urinary excretion of $\mathrm{Cr}^{51}$. The chief advantage of washing the red cells prior to injection is to obviate an initial urinary hyperexcretion of $\mathrm{Cr}^{51}$ which is not derived from labelled red cells but from the plasma. The injection of a small amount of $\mathrm{Cr}^{51}$ unattached to red cells will also impair the accuracy of the initial blood volume determinations if whole blood specimen radioactivity is measured, but it should not interfere with the assessment of splenic sequestering activity.

The extensive accumulation of $\mathrm{Cr}^{51}$ observed to occur in the spleens and livers of patients with hemolytic anemias necessitates a re-appraisal of the radiation hazard involved. The radiation dosage contributed by the injection of $100 \mu \mathrm{C}$ of $\mathrm{Cr}^{51}$ into a $70 \mathrm{Kg}$. subject has been estimated to be about 0.1 rep, with the assumption that the isotope is evenly distributed within the circulation and that no excretion has occurred (24). In a patient with a hemolytic process in which the injected $\mathrm{Cr}^{51}$ is accumulated entirely by the liver and spleen, with combined organ weights of 1600 grams, the exposure to these tissues approximates 2.0 rep. If a $100 \mu \mathrm{C}$ dose of $\mathrm{Cr}^{51}$ is accumulated entirely by a 200 -gram spleen, the exposure to that organ will approximate 16.1 rep, an excessive level. Although total clearance of $\mathrm{Cr}^{51}$ by the spleen is unlikely, it is suggested that the dose of $\mathrm{Cr}^{51}$ employed in subjects with presumed hemolytic anemias be reduced to a maximum of $50 \mu \mathrm{C}$.

\section{Cr $r^{51}$ in predicting the need for splenectomy}

After each injection of labelled red cells determination of the body surface $\mathrm{Cr}^{51}$ activity by means of three or four appropriately spaced sets of observations over precordium, liver, spleen and 
thorax should suffice to establish the sites of red cell sequestration. For correlation with the rates of disappearance of $\mathrm{Cr}^{51}$-labelled red cells from the peripheral blood it is desirable to perform body surface counts for at least half the red cell survival period. A suggested procedure is to make a set of observations 20 or 30 minutes after the injection of labelled red cells and again one day later. Two or three more observations of body surface radioactivity (for example, after an estimated 25 per cent, 50 per cent, and 90 per cent, respectively, of the labelled cells have been destroyed) should provide the desired information. Employment of a uniform, geometric positioning of patients and of counting apparatus at the time of each observation is, of course, essential to obtaining reproducible data. Nevertheless, a portable counting unit at the bedside should be sufficiently accurate to determine the approximate distribution of radioactivity between heart, liver, and spleen.

The in vivo determination of the site of red cell sequestration should prove of greatest practical value in predicting the need for splenectomy in acquired hemolytic anemias, wherein the greatest prognostic uncertainty presently exists. Interpretation of the data obtained by the methods described may be simplified by using a standardized expression such as the difference between the relative radioactivity (expressed as a percentage of that over the precordium) for liver or spleen at the red cell half-survival time $\left(R_{50}\right)$ and such values at zero time $\left(R_{0}\right)$. A simple formula may then be invoked as an index of red cell sequestration as follows:

$$
\text { Index of Sequestration }=R_{50}-R_{0}
$$

In 3 normal subjects, these values for the liver ranged from 23 to 35 and for the spleen from 38 to 48 with average values of 27 and 43 , respectively, as recorded in Table I. A tentative grading of the intensity of splenic sequestration on the basis of the index of sequestration values recorded in Table I for the 11 anemic subjects might be as follows: less than 30-subnormal; 30 to 60-normal; 60 to 100 -mild to moderate; and greater than 100 -moderate to severe. The employment of even such crude numerical assessments as guides in deciding the need for splenectomy will assuredly require many case studies. However,
Korst, Clatanoff, and Schilling (25) have studied, with methods resembling ours, 3 patients with acquired hemolytic anemia, on whom splenectomies were later performed. In 2 of the patients high splenic accumulations of $\mathrm{Cr}^{51}$ occurred and splenectomy was beneficial; in 1 patient, in whom there was little build-up of radioactivity over the spleen, removal of the spleen was ineffectual. There are, in addition to this category of patients, other conditions sometimes characterized by splenomegaly $(23,26-28)$ in which, although splenectomy is usually not indicated, in individual instances removal of the spleen has benefitted the patient by decreasing the rate of red cell destruction (26-28). An unexpected example eventuated from the observation that radioactivity accumulated in the enlarged spleen of a patient, Case 5, with paroxysmal nocturnal hemoglobinuria following injection of $\mathrm{Cr}^{51}$-labelled red cells. Removal of the patient's 660-gram spleen produced temporarily a moderate diminution of the anemia, and thereafter the patient has required fewer transfusions to maintain a given hemoglobin concentration. It is likely that detectable instances of excessive sequestration by pathologic spleens will arise in a variety of disease states. The surprising predilection of $\mathrm{Cr}^{51}$-labelled pernicious anemia red cells for sequestration by the spleen, observed in Case 8, may explain the therapeutic value of splenectomy reported in this disease prior to the use of liver extract (29). The fact that the defectively formed red cells characteristic of certain diseases of red cell underproduction may survive poorly, and, as in the case of pernicious anemia, despite a calculated rate of hemoglobin production that was subnormal, may be detectably sequestered by the spleen, enjoins the need to characterize the fundamental balance between red cell production and destruction in each case as clearly as possible. The anemia of chronic liver disease, for example, has been shown to be primarily hemolytic in most instances (14). The finding that all of 4 patients with the anemia of liver disease demonstrated mild to moderate splenic uptakes of $\mathrm{Cr}^{51}$, as illustrated by Case 7, indicates the potential therapeutic value of splenectomy in such patients although only rarely is such an operation warranted. The occasional patients with congenital non-spherocytic hemolytic anemia who may benefit from splenectomy should also be identifiable by the $\mathrm{Cr}^{51}$ distribution technique. 


\section{SUMMARY}

The sites of deposition of $\mathrm{Cr}^{51}$ in the human body were determined by body surface counting following the injection into normal subjects of $\mathrm{Cr}^{51}$-labelled red cells, hemoglobin, and chromic chloride in saline. Differences characteristic of each were observed and served as a basis for interpretation of a study of a series of 11 patients with hemolytic anemias of diverse kinds. Measurements made on these patients following injection of $\mathrm{Cr}^{51}$-labelled autologous red cells suggested that progressive accumulation of $\mathrm{Cr}^{51}$ in the spleen accompanying the disappearance of $\mathrm{Cr}^{51}$-labelled red cells from the blood stream indicates active red cell sequestration. In determining the extent of this sequestration a simple expression may be employed (index of sequestration) which deducts that radioactivity initially present and due simply to the size of the splenic vascular bed from later values obtained over that organ. The methods described should in practice constitute a simple clinical device for determining the need for splenectomy. In certain hemolytic anemias the short survival of labelled red cells in the circulation is accompanied by a progressive increase of radioactivity over the spleen and the anemia is relieved by splenectomy.

\section{ACKNOWLEDGMENTS}

We are indebted to Miss Martha Hoge, Miss Patricia Lambert, Miss Nancy Sheldon, and Miss Ann Tomlinson for technical assistance.

\section{REFERENCES}

1. Ham, T. H., and Castle, W. B., Relation of increased hypotonic fragility and of erythrostasis to the mechanism of hemolysis in certain anemias. Tr. A. Am. Physicians, 1940, 55, 127.

2. Emerson, C. P., Jr., Shen, S. C., and Castle, W. B., The osmotic fragility of the red cells of the peripheral and splenic blood in patients with congenital hemolytic jaundice transfused with normal red cells. J. Clin. Invest., 1946, 25, 922.

3. Emerson, C. P., Jr., Shen, S. C., Ham, T. H., and Castle, W. B., The mechanism of blood destruction in congenital hemolytic jaundice. J. Clin. Invest., 1947, 26, 1180.

4. Young, L. E., Platzer, R. F., Ervin, D. M., and Izzo, M. J., Hereditary spherocytosis. II. Observations on the role of the spleen. Blood, 1951, 6, 1099.
5. Weisman, R., Jr., Hurley, T. H., Harris, J. W., and Ham, T. H., Studies of the function of the spleen in the hemolysis of red cells in hereditary spherocytosis and sickle cell disorders. J. Lab. \& Clin. Med., 1953, 42, 965.

6. Diggs, L. W., and Ching, R. E., Pathology of sickle cell anemia. South. M. J., 1934, 27, 839.

7. Bauer, J., Sickle cell disease. Pathogenic, clinical and therapeutic considerations. Arch. Surg., 1940, 41, 1344.

8. Gray, S. J., and Sterling, $K$., The tagging of red cells and plasma proteins with radioactive chromium. J. Clin. Invest., 1950, 29, 1604.

9. Jandl, J. H., Sequestration by the spleen of red cells sensitized with incomplete antibody and with metallo-protein complexes. J. Clin. Invest., 1955, 34, 912.

10. Jandl, J. H., Greenberg, M. S., Yonemoto, R. H., and Castle, W. B., Clinical determination of the sites of red cell destruction. Clin. Res. Proc., 1955, 3, 95.

11. Ham, T. H., Ed., A syllabus of laboratory examinations in clinical diagnosis. Critical evaluation of laboratory procedures in the study of the patient. Cambridge, Harvard University Press, 1950.

12. Ebaugh, F. G., Jr., Emerson, C. P., and Ross, J. F., The use of radioactive chromium ${ }^{\text {sit }}$ as an erythrocyte tagging agent for the determination of red cell survival in vivo. J. Clin. Invest., 1953, 32, 1260.

13. Jandl, J. H., To be published.

14. Jandl, J. H., The anemia of liver disease: Observations on its mechanism. J. Clin. Invest., 1955, 34, 390.

15. Loutit, J. F., Discussion on the life and death of the red blood corpuscle. Proc. Roy. Soc. Med., 1946, 39, 757.

16. Singer, K., King, J. C., and Robin, S., The life span of the megalocyte and the hemolytic syndrome of pernicious anemia. J. Lab. \& Clin. Med., 1948, 33, 1068.

17. Emerson, C. P., Jr., and Burrows, B. A., The mechanism of anemia and its influence on renal function in chronic uremia. J. Clin. Invest., 1949, 28, 779.

18. Loge, J. P., Lange, R. D., and Moore, C. V., Characterization of the anemia of chronic renal insufficiency. J. Clin. Invest., 1950, 29, 830.

19. Chaplin, H., Jr., and Mollison, P. L., Red cell lifespan in nephritis and in hepatic cirrhosis. Clin. Sc., 1953, 12, 351.

20. Finch, C. A., Hegsted, M., Kinney, T. D., Thomas, E. D., Rath, C. E., Haskins, D., Finch, S., and Fluharty, R. G., Iron metabolism. The pathophysiology of iron storage. Blood, 1950, 5, 983.

21. Visek, W. J., Whitney, I. B., Kuhn, U. S. G., III, and Comar, C. L., Metabolism of $\mathrm{Cr}^{\mathrm{e}}$ by animals as influenced by chemical state. Proc. Soc. Exper. Biol. \& Med., 1953, 84, 610. 
22. Diggs, L. W., Siderofibrosis of the spleen in sickle cell anemia. J.A.M.A., 1935, 104, 538.

23. Lichtman, H., Shapiro, H., Ginsberg, V., and Watson, J., Splenic hyperfunction in sickle cell anemia. Am. J. Med., 1953, 14, 516.

24. Frank, H., and Gray, S. J., The determination of plasma volume in man with radioactive chromic chloride. J. Clin. Invest., 1953, 32, 991.

25. Korst, D. R., Clatanoff, D. V., and Schilling, R. F., External scintillation counting over the liver and spleen after the transfusion of radioactive erythrocytes. Clin. Res. Proc., 1955, 3, 195.

26. Hahn, E. V., and Gillespie, E. B., Sickle cell anemia. Report of a case greatly improved by splenectomy.
Experimental study of sickle cell formation. Arch. Int. Med., 1927, 39, 233.

27. Shotton, D., Crockett, C. L., Jr., and Leavell, B. S., Splenectomy in sickle cell anaemia: Report of a case and review of the literature. Blood, 1951, 6, 365.

28. Lichtman, H. C., Watson, R. J., Feldman, F., Ginsberg, V., and Robinson, J., Studies on thalassemia. Part II. The effects of splenectomy in thalassemia major with an associated acquired hemolytic anemia. J. Clin. Invest., 1953, 32, 1233.

29. Pearce, R. M., Krumbhaar, E. B., and Frazier, C. H., The Spleen and Anemia. Experimental and Clinical Studies. Phila. and London, J. B. Lippincott, 1918. 